\title{
Preparation and Hydrosilylation Activity of a
}

\section{Molybdenum Carbonyl Complex that Features a}

\section{Pentadentate Bis(imino)pyridine Ligand}

Raja Pal,,$^{\dagger}$ Thomas L. Groy, ${ }^{\dagger}$ Amanda C. Bowman, ${ }^{\not,}$ Ryan J. Trovitch ${ }^{*}, \dagger$

${ }^{\dagger}$ Department of Chemistry \& Biochemistry, Arizona State University, Tempe, Arizona 85287

${ }^{*}$ Department of Chemistry, Transylvania University, Lexington, Kentucky 40508

ABSTRACT. Attempts to prepare low-valent molybdenum complexes that feature a pentadentate 2,6-bis(imino)pyridine (or pyridine diimine, PDI) chelate allowed for the isolation of two different products. Refluxing $\mathrm{Mo}(\mathrm{CO})_{6}$ with the pyridine-substituted PDI ligand, ${ }^{\mathrm{PyEt}} \mathrm{PDI}$, resulted in carbonyl ligand substitution and formation of the respective bis(ligand) compound, $\left({ }^{\mathrm{PyEt}} \mathrm{PDI}\right)_{2} \mathrm{Mo}(\mathbf{1})$. This complex was investigated by single crystal X-ray diffraction and density functional theory (DFT) calculations indicated that 1 possesses a $\operatorname{Mo}(0)$ center that backbonds into the $\pi^{*}$-orbitals of the unreduced PDI ligands. Heating an equimolar solution of $\mathrm{Mo}(\mathrm{CO})_{6}$ and the phosphine-substituted PDI ligand, ${ }^{\mathrm{Ph}}{ }^{\mathrm{PPr}} \mathrm{PDI}$, to $120{ }^{\circ} \mathrm{C}$ allowed for the preparation of $\left({ }^{\mathrm{Ph}}{ }_{2} \mathrm{Pr} P D I\right) \mathrm{Mo}(\mathrm{CO})(\mathbf{2})$, which is supported by a $\kappa^{5}-N, N, N, P, P_{-}{ }^{\mathrm{Ph}}, \mathrm{Pr} P D I$ chelate. Notably, $\mathbf{1}$ and $\mathbf{2}$ have been found to catalyze the hydrosilylation of benzaldehyde at $90{ }^{\circ} \mathrm{C}$, and the optimization of 2-catalyzed aldehyde hydrosilylation at this temperature afforded turnover frequencies (TOFs) 
of up to $330 \mathrm{~h}^{-1}$. Considering additional experimental observations, the potential mechanism of 2-mediated carbonyl hydrosilylation is discussed.

INTRODUCTION. Homogeneous transition metal complexes capable of mediating the efficient and selective reduction of $\mathrm{C}=\mathrm{C}$ and $\mathrm{C}=\mathrm{O}$ bonds have long been sought and studied by coordination chemists. ${ }^{1}$ While hydrogenation catalysts have become vastly utilized for the synthesis of pharmaceuticals and other fine chemicals, ${ }^{2}$ hydrosilylation catalysts have enabled the production of a wide range of silicone coatings and adhesives. ${ }^{3}$ Most industrial-scale hydrosilylation processes rely on precious metal catalysts due to their activity and stability; ${ }^{4}$ however, such catalysts are not always desirable because of their high cost and inherent toxicity. ${ }^{5}$ These characteristics have inspired the search for non-precious metal hydrosilylation catalysts that operate with competitive activities, selectivities, and catalyst lifetimes. ${ }^{6}$ This motivation has led researchers to develop numerous inexpensive and sustainable $\mathrm{Mn},{ }^{7} \mathrm{Fe},{ }^{8} \mathrm{Co},{ }^{9}$ and $\mathrm{Ni}^{10}$ hydrosilylation catalysts.

While the focus on late first-row transition metal hydrosilylation catalysis continues to intensify, ${ }^{11}$ the investigation of homogenous Mo-based reduction catalysis has remained relatively overlooked, even though this metal is non-toxic ${ }^{12}$ and relatively abundant in the earth's crust $(1.2 \mathrm{mg} / \mathrm{kg}) .{ }^{13}$ Well-defined Mo complexes that mediate the hydrogenation of $\mathrm{C}=\mathrm{C}^{14,15}$ and $\mathrm{C}=\mathrm{O}$ bonds ${ }^{16,17}$ have been studied; however, the activity of these catalysts has remained limited to $<50 \mathrm{~h}^{-1}$ at $100{ }^{\circ} \mathrm{C}$, which was reported for $\mathrm{Mo}(\mathrm{CO})_{3}(\mathrm{NCMe})\left(\mathrm{PPh}_{3}\right)_{2}$-mediated olefin hydrogenation. ${ }^{15}$ Mo-based alkene hydrosilylation catalysts have also been described; ${ }^{14,18}$ however, coordination chemists have been far more successful in developing robust and highly active Mo catalysts that mediate $\mathrm{C}=\mathrm{O}$ bond hydrosilylation. In 2003, Dioumaev and Bullock reported that $\left[\mathrm{CpMo}(\mathrm{CO})_{2}(\mathrm{IMes})\right]\left[\mathrm{B}\left(\mathrm{C}_{6} \mathrm{~F}_{5}\right)_{4}\right]$ is active for the hydrosilylation of 3-pentanone at 
$23{ }^{\circ} \mathrm{C}$; however, the initial TOF of $10 \mathrm{~h}^{-1}$ recorded for this transformation was inferior to the TOFs observed for the tungsten congener of this complex $\left(370 \mathrm{~h}^{-1}\right) \cdot{ }^{19}$ Research conducted by the Royo $^{20}$ and Abu-Omar ${ }^{21}$ groups has demonstrated that Mo(IV) dioxo complexes can catalyze the hydrosilylation of aldehydes and ketones with TOFs of up to $80 \mathrm{~h}^{-1}$ at $25{ }^{\circ} \mathrm{C} .{ }^{20 \mathrm{~b}}$ Similar TOFs for the hydrosilylation of aldehydes using several related Mo(IV) imido complexes have since been reported by the Nikonov group. ${ }^{22} \mathrm{Mo}(0)$ hydrosilylation catalysts have also been described ${ }^{23}$ and Berke and co-workers recently revealed that $\left[(\mathrm{DPEphos}) \mathrm{Mo}(\mathrm{NO})(\mathrm{NCMe})_{3}\right]\left[\mathrm{BAr}_{4}^{\mathrm{F}}\right]$ can mediate the hydrosilylation of aldehydes with TOFs of up to $4864 \mathrm{~h}^{-1}$ at $120^{\circ} \mathrm{C}$ and the hydrosilylation of ketones with initial TOFs of up to $32,000 \mathrm{~h}^{-1}$ at $120{ }^{\circ} \mathrm{C}^{24}$

With this precedent in mind, we hypothesized that it might be possible to design a low-valent Mo hydrosilylation catalyst that is bound to a single donor-substituted PDI ligand, rather than the set of bidentate and monodentate ligands that comprise $\left[(\mathrm{DPEphos}) \mathrm{Mo}(\mathrm{NO})(\mathrm{NCMe})_{3}\right]\left[\mathrm{BAr}_{4}^{\mathrm{F}}\right]$. Our group has recently utilized this methodology ${ }^{25}$ to prepare a formally zerovalent Mn complex, $\left({ }^{\mathrm{Ph}}{ }_{2}^{\mathrm{PPr}} \mathrm{PDI}\right) \mathrm{Mn},{ }^{7 \mathrm{i}}$ that catalyzes ketone hydrosilylation with TOFs of up $76,800 \mathrm{~h}^{-1}$ at ambient temperature. Herein, we describe our efforts to prepare Mo complexes that feature a pentadentate PDI ligand, as well as the hydrosilylation activity of the isolated products. 
RESULTS AND DISCUSSION. This project commenced with the synthesis of 2,6-bis[1-(2ethylpyridylimino)ethyl]pyridine ( $\left.{ }^{\mathrm{PyEt}} \mathrm{PDI}\right)$, which we hoped would coordinate to low-valent Mo in a $\kappa^{5}-N, N, N, N, N$-fashion. Although $\left({ }^{\mathrm{PyEt}} \mathrm{PDI}\right)$ had previously been prepared in low yield $(24.6 \%)$ by heating a benzene solution of 2,6-diacetylpyridine and 2-aminoethylpyridine, ${ }^{26}$ it was discovered that yields of up to $96 \%$ could be obtained upon heating a toluene solution of these starting materials, a catalytic amount of $p$-toluenesulfonic acid, and $4 \AA$ molecular sieves in a thick-walled glass bomb to $80{ }^{\circ} \mathrm{C}$. With ${ }^{\text {PyEt}} \mathrm{PDI}$ in hand, a stoichiometric amount of this ligand was added to a $m$-xylene solution of $\mathrm{Mo}(\mathrm{CO})_{6}$ and heating to $130{ }^{\circ} \mathrm{C}$ for 2 days produced a brown colored solution that offered evidence for ${ }^{\text {PyEt}} \mathrm{PDI}$ metallation by ${ }^{1} \mathrm{H}$ NMR spectroscopy. Because appreciable amounts of the newly formed product could not be isolated from this reaction, the stoichiometry was modified such that 2 equivalents of ${ }^{\text {PyEt}}$ PDI were added per $\mathrm{Mo}(\mathrm{CO})_{6}$ equivalent. This adjustment allowed the isolation and full characterization of the respective bis(ligand) compound, $\left({ }^{\mathrm{PyEt}} \mathrm{PDI}\right)_{2} \mathrm{Mo}$ (equation 1, 1). Alternatively, this complex has been prepared by reducing (py) ${ }_{3} \mathrm{MoCl}_{3}{ }^{27}$ with excess $\mathrm{Na}$ amalgam in the presence of 2 equivalents of ${ }^{\text {PyEt} P D I . ~}$

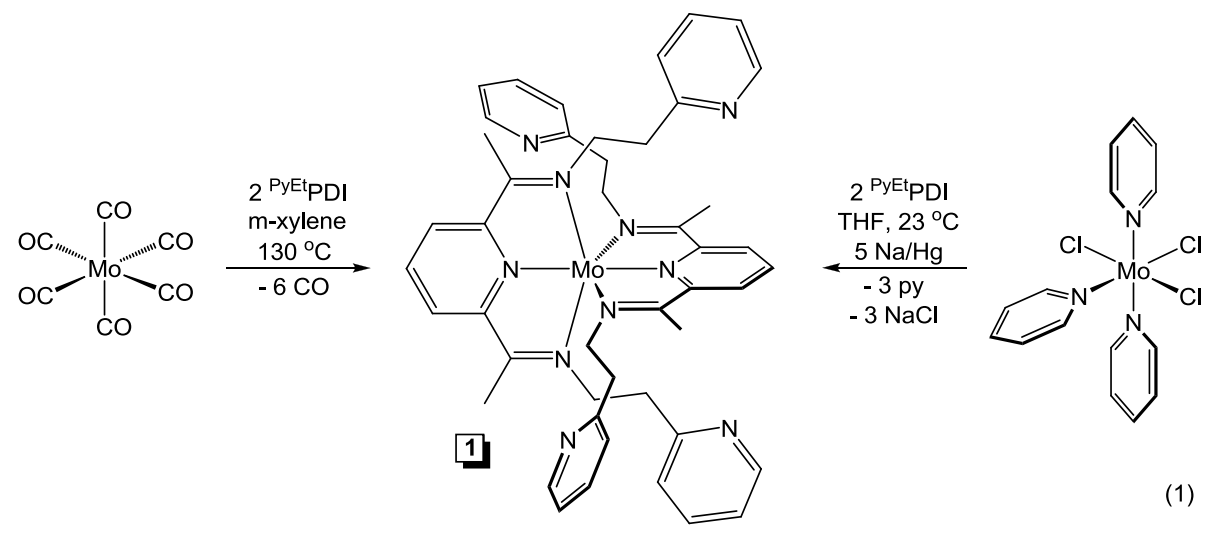


To confirm the identity of $\mathbf{1}$, single crystals of this complex were grown from a concentrated pentane solution at $-35{ }^{\circ} \mathrm{C}$ and further analyzed by X-ray diffraction. The solid state structure of 1 (Figure 1) confirmed that each ${ }^{\text {PyEt}} \mathrm{PDI}$ chelate is coordinated to the metal center in a terdentate fashion and that the overall geometry about Mo is best described as distorted octahedral, with $\mathrm{N}(2)-\mathrm{Mo}(1)-\mathrm{N}(2 \mathrm{~A})$ and $\mathrm{N}(1)-\mathrm{Mo}(1)-\mathrm{N}(3)$ angles of 179.7(2) and 147.55(15) ${ }^{\circ}$, respectively. Although several reports have demonstrated the coordination of bis(imino)pyridine chelates to $\mathrm{Mo},{ }^{28}$ only one other complex featuring $\kappa^{3}-N, N, N$-PDI ligation has been crystallographically characterized to date; $\left({ }^{\mathrm{E}} \mathrm{E}^{\mathrm{Ar}} \mathrm{PDI}\right) \mathrm{MoCl}_{3} .{ }^{29}$ This complex was found to have chelate bond distances that are consistent with minimal backbonding from the Mo(III) center to the $\pi^{*}$ orbitals of ${ }_{2}^{\mathrm{E}} \mathrm{Ar} \mathrm{PDI}\left(\mathrm{N}_{\text {imine }}-\mathrm{C}_{\text {imine }}=1.24(2), 1.31(2) \AA ; \mathrm{C}_{\text {imine }}-\mathrm{C}_{\text {pyridine }}=1.49(3), 1.51(3) \AA\right)$. In contrast, the bond distances established for the bis(imino)pyridine framework of $\mathbf{1}$ (Table 1) indicate that a significant amount of electron density is being transferred from the metal center to the $\pi$-system of each chelate, as might be expected for a formally zerovalent Mo complex. This is most apparent when considering the elongated $\mathrm{N}(1)-\mathrm{C}(2)$ and $\mathrm{N}(3)-\mathrm{C}(8)$ distances of 1.335(6) and 1.351(6) $\AA$, as well as the contracted $\mathrm{C}(2)-\mathrm{C}(3)$ and $\mathrm{C}(7)-\mathrm{C}(8)$ distances of 1.419(7) and 1.420(7) $\AA$ Å, determined for $\mathbf{1}$. 


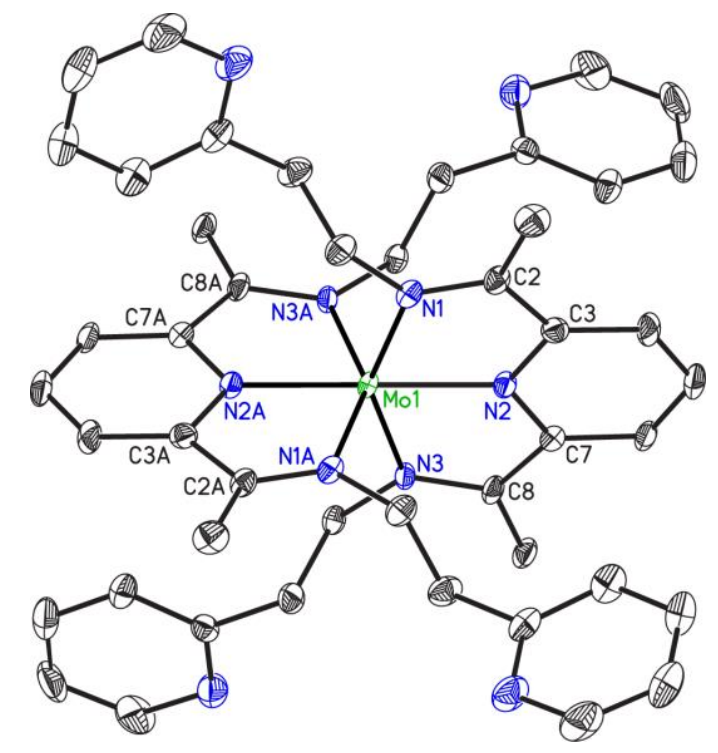

Figure 1. The solid state structure of 1 shown at 30\% probability ellipsoids. Hydrogen atoms and co-crystallized pentane molecule are omitted for clarity.

Table 1. Experimental and calculated (RKS and RKS/COSMO) bond lengths $(\AA)$ and angles $\left(^{\circ}\right)$ for 1.

\begin{tabular}{|lccc|}
\hline \hline & $\mathbf{1}$ & RKS & RKS/COSMO \\
\hline \hline Mo(1)-N(1) & $2.078(4)$ & 2.115 & 2.093 \\
Mo(1)-N(2) & $2.026(4)$ & 2.040 & 2.038 \\
$\operatorname{Mo}(1)-\mathrm{N}(3)$ & $2.074(4)$ & 2.113 & 2.086 \\
$\mathrm{~N}(1)-\mathrm{C}(2)$ & $1.335(6)$ & 1.340 & 1.337 \\
$\mathrm{~N}(3)-\mathrm{C}(8)$ & $1.351(6)$ & 1.341 & 1.340 \\
$\mathrm{C}(2)-\mathrm{C}(3)$ & $1.419(7)$ & 1.423 & 1.421 \\
$\mathrm{C}(7)-\mathrm{C}(8)$ & $1.420(7)$ & 1.423 & 1.420 \\
$\mathrm{~N}(2)-\mathrm{C}(3)$ & $1.407(6)$ & 1.400 & 1.402 \\
$\mathrm{~N}(2)-\mathrm{C}(7)$ & $1.405(6)$ & 1.400 & 1.403 \\
& & & \\
$\mathrm{~N}(1)-\mathrm{Mo}(1)-\mathrm{N}(1 \mathrm{~A})$ & $86.8(2)$ & 87.34 & 91.11 \\
$\mathrm{~N}(1)-\mathrm{Mo}(1)-\mathrm{N}(3)$ & $147.55(15)$ & 147.44 & 147.26 \\
$\mathrm{~N}(1)-\mathrm{Mo}(1)-\mathrm{N}(3 \mathrm{~A})$ & $102.09(15)$ & 101.58 & 97.16 \\
$\mathrm{~N}(2)-\mathrm{Mo}(1)-\mathrm{N}(2 \mathrm{~A})$ & $179.7(2)$ & 179.71 & 176.40 \\
\hline
\end{tabular}


Since the redox non-innocent nature of bis(imino)pyridine ligands has been widely publicized, ${ }^{30-}$ 32 one must consider whether $\mathbf{1}$ is best described as having a $\operatorname{Mo}(0)$ center that simply backbonds into the $\pi$-system of each PyEt PDI ligand or as having an oxidized Mo center that is supported by radical monoanion or dianionic chelates. Although the bond distances determined for $\mathbf{1}$ might suggest that each chelate is reduced by at least one electron (one electron reduction: $\mathrm{C}_{\mathrm{imine}}-\mathrm{N}_{\text {imine }}$ $=1.32 \AA, C_{\text {imine }}-C_{\text {pyridine }}=1.44 \AA$; two electron reduction: $C_{\text {imine }}-\mathrm{N}_{\text {imine }}=1.36 \AA, C_{\text {imine }}-C_{\text {pyridine }}=$ $1.40 \AA),{ }^{31}$ recent work to determine the electronic structure of related $\left({ }^{\mathrm{Me}_{3} \mathrm{Ar}} \mathrm{DI}\right)_{2} \mathrm{Mo}(\mathrm{CO})_{2}(\mathrm{DI}=$ $\alpha$-diimine) complexes has revealed that they possess $\operatorname{Mo}(0)$ metal centers, even though the DI structural parameters are consistent with single electron reduction. ${ }^{33}$ To further investigate the electronic structure of $\mathbf{1}$, density functional theory (DFT) calculations were performed at the B3LYP level of theory. The bond distances and angles found within the restricted Kohn-Sham (RKS, closed shell) and RKS with applied Conductor-like Screening Model (RKS/COSMO, accounts for solvent effects) solutions for $\mathbf{1}$ (Table 1) are consistent with the experimentally determined values. The HOMO, HOMO-1 and HOMO-2 orbitals of $\mathbf{1}$ are highly covalent and reveal significant metal to ligand backbonding (25-39\% Mo, see Scheme S1 of the Supporting Information). Furthermore, attempts to calculate the open shell singlet (unrestricted Kohn-Sham, UKS with $S=0$ ) converged to the closed-shell solution, while the open shell triplet (UKS with S =1) was geometrically distorted and found to be approximately $20 \mathrm{kcal} / \mathrm{mol}$ higher in energy than the RKS solution (See Table S4 of the Supporting Information). These results indicate that 1 can best be described as having a zerovalent metal center that engages in backbonding with each ${ }^{\text {PyEt}}$ PDI ligand.

Having determined that ${ }^{\text {PyEt }}$ PDI displaces the carbonyl ligands of $\mathrm{Mo}(\mathrm{CO})_{6}$, we hypothesized that incorporating high field strength donors within each imine substituent might allow the 
preparation of a zerovalent Mo complex featuring $\kappa^{5}$-, rather than $\kappa^{3}$-PDI coordination. Knowing that the phosphine-substituted chelate, ${ }^{\mathrm{Ph}}{ }_{2} \mathrm{PPr} P D I$ (equation 2), can coordinate to low-valent $\mathrm{Rh}^{34}$ and $\mathrm{Mn}^{7 \mathrm{i}}$ in a pentadentate fashion, a stoichiometric quantity of this chelate was added to a toluene solution of $\mathrm{Mo}(\mathrm{CO})_{6}$ and the reaction was heated to $120^{\circ} \mathrm{C}$ for $48 \mathrm{~h}$. The resulting pink product was analyzed by multinuclear NMR spectroscopy and was found to exhibit a single ${ }^{31} \mathrm{P}$ NMR resonance at $34.88 \mathrm{ppm}$. Furthermore, this complex was found to possess six ligand methylene environments by ${ }^{1} \mathrm{H}$ NMR spectroscopy (expected for a complex that contains a $C_{2}$ rotation axis and top-to-bottom chelate inequivalence), ${ }^{34}$ confirming that ${ }^{\mathrm{Ph}_{2} \mathrm{PPr}} \mathrm{PDI}$ chelate was coordinated in a pentadentate fashion. Analysis of this complex by IR spectroscopy revealed a single $\mathrm{CO}$ stretch at $1740 \mathrm{~cm}^{-1}$, suggesting that the newly formed complex retains one $\mathrm{CO}$ ligand that is accepting a significant amount of electron density via $\pi$-backbonding from the Mo center. This stretching frequency is slightly lower than those reported for trans$\left[\mathrm{Mo}(\mathrm{CO})\left(\mathrm{NC}^{\mathrm{n}} \mathrm{Pr}\right)\left(\mathrm{Ph}_{2} \mathrm{PCH}_{2} \mathrm{CH}_{2} \mathrm{PPh}_{2}\right)_{2}\right]\left(v_{\mathrm{CO}}=1745 \mathrm{~cm}^{-1}\right)^{35}$ and $\left[\mathrm{Mo}(\mathrm{CO})\left(\mathrm{Et}_{2} \mathrm{PCH}_{2} \mathrm{CH}_{2} \mathrm{PEt}_{2}\right)_{2}\right]\left(\mu-\mathrm{N}_{2}\right)\left(v_{\mathrm{CO}}=1747 \mathrm{~cm}^{-1}\right)^{36}$ but higher than those reported for $\left[\mathrm{Mo}(\mathrm{CO})\left(\mathrm{Et}_{2} \mathrm{PCH}_{2} \mathrm{CH}_{2} \mathrm{PEt}_{2}\right)_{2}\right]\left(v_{\mathrm{CO}}=1721 \mathrm{~cm}^{-1}\right)$ and $\left[\mathrm{Mo}(\mathrm{CO})\left({ }^{\mathrm{i}} \mathrm{Bu}_{2} \mathrm{PCH}_{2} \mathrm{CH}_{2} \mathrm{P}^{\mathrm{i}} \mathrm{Bu}_{2}\right)_{2}\right]\left(v_{\mathrm{CO}}=\right.$ $1724 \mathrm{~cm}^{-1}$ ), which feature an agostic $\mathrm{C}-\mathrm{H}$ bond trans to $\mathrm{CO} .{ }^{36}$ Taken together, this data suggested that the newly prepared complex was six-coordinate, $\left({ }^{\mathrm{Ph}}{ }_{2} \mathrm{PPr} P D I\right) \mathrm{Mo}(\mathrm{CO})(\mathbf{2}$, equation 2).

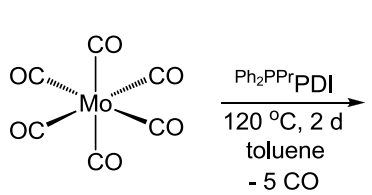

(2)

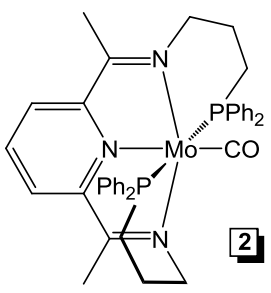

An isolated crystal of $\mathbf{2}$ was then analyzed by single crystal X-ray diffraction to determine the overall geometry about Mo, as well as the existing degree of metal to ${ }^{\mathrm{Ph}_{2} \mathrm{PPr}} \mathrm{PDI} \pi$-backbonding. 
The solid state structure (Figure 2) and metrical parameters (Table 2) determined for $\mathbf{2}$ reveal a few surprising characteristics. The geometry about the Mo center in $\mathbf{2}$ is significantly distorted from an idealized octahedron with $\mathrm{N}(1)-\mathrm{Mo}(1)-\mathrm{N}(3)$ and $\mathrm{P}(1)-\mathrm{Mo}(1)-\mathrm{P}(2)$ angles of 147.91(15) and $155.46(5)^{\circ}$, respectively. More importantly, the carbonyl ligand is not linearly oriented with the pyridine functionality of ${ }^{\mathrm{Ph}_{2} \mathrm{PPr}} \mathrm{PDI}$. In turn, the $\mathrm{N}(2)-\mathrm{Mo}(1)-\mathrm{C}(40)$ and $\mathrm{N}(1)-\mathrm{Mo}(1)-\mathrm{C}(40)$ angles of $171.43(18)$ and $97.74(18)^{\circ}$, respectively, appear to dictate how the Mo center in 2 engages in $\pi$-backbonding. It is believed that the solid state positioning of the carbonyl ligand serves to maximize its ability to participate in $\pi$-backdonation together with the $\mathrm{N}(1)$-C(2) PDI imine arm [i.e., both $\mathrm{N}(1)$ and $\mathrm{C}(40)$ appear to lie on principal Mo bonding axes since these atoms form an angle of close to $90^{\circ}$ ]. Upon examining the $\mathrm{C}_{\text {imine }}-\mathrm{N}_{\text {imine }}$ and $\mathrm{C}_{\text {imine }}-\mathrm{C}_{\text {pyridine }}$ chelate distances, it is clear that the electron density transferred to ${ }^{\mathrm{Ph}}{ }_{2} \mathrm{Pr} P D I$ via backdonation is localized between $\mathrm{N}(1)$ and $\mathrm{N}(2)$, as $\mathrm{N}(1)-\mathrm{C}(2)$ and $\mathrm{N}(2)-\mathrm{C}(3)$ are elongated to 1.362(6) and 1.390(6) $\AA$, respectively, while $\mathrm{C}(2)-\mathrm{C}(3)$ is significantly shortened to $1.402(7) \AA{ }^{31}$ This contrasts the distances found for $\mathrm{N}(3)-\mathrm{C}(8), \mathrm{C}(7)-\mathrm{C}(8)$, and $\mathrm{N}(2)-\mathrm{C}(7)$, which indicate poorer Mo-PDI $\pi$ overlap. These parameters suggest that 2 can best be described as having a $\operatorname{Mo}(0)$ center that participates in $\pi$-backbonding since a PDI chelate that is reduced by one or more electrons would likely exhibit complete electron delocalization. ${ }^{37}$ 

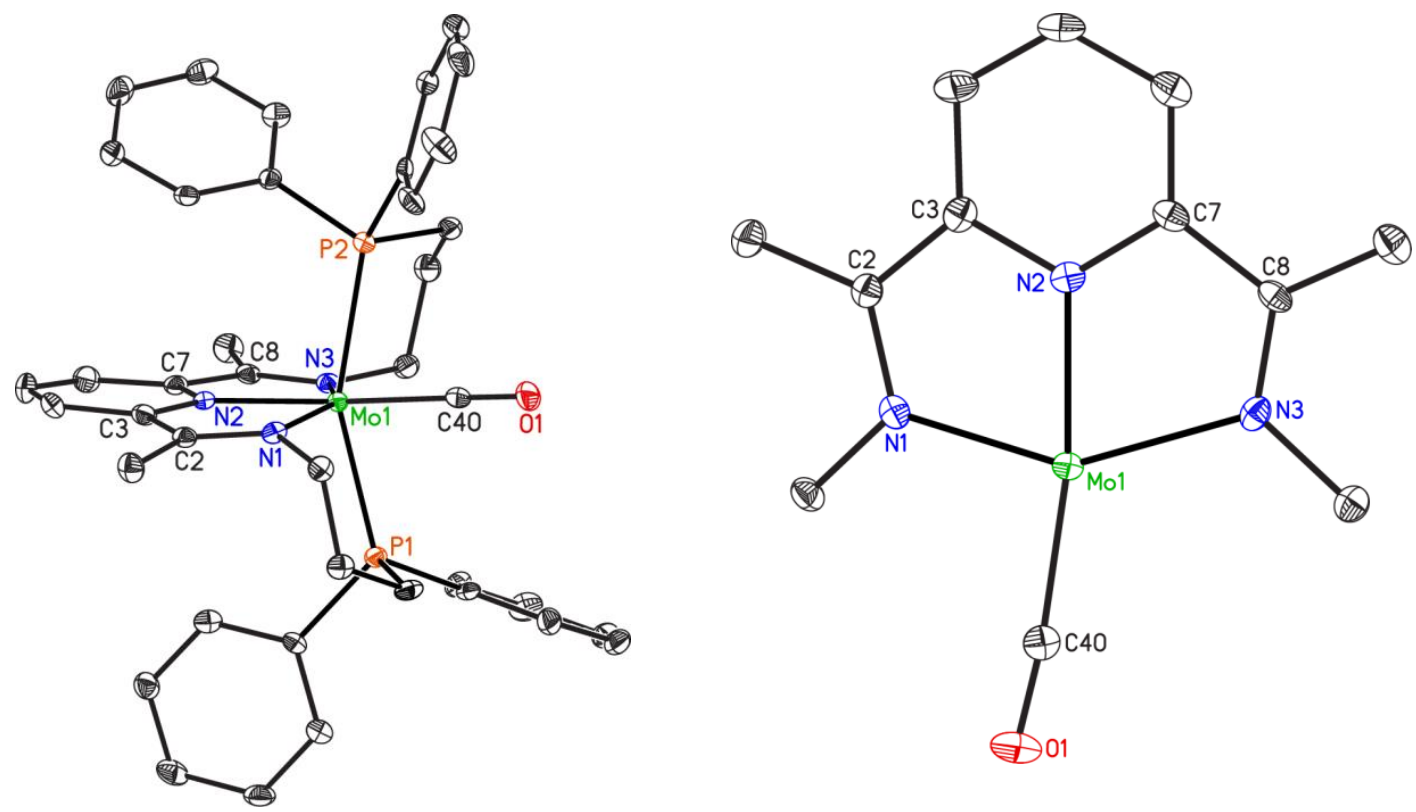

Figure 2. The solid state structure of 2 shown at 30\% probability ellipsoids (left). A view of the bis(imino)pyridine/carbonyl plane with the chelate ligand arms removed for clarity (right). Hydrogen atoms and a disordered, co-crystallized diethyl ether molecule have been omitted from each rendering.

Table 2. Experimental bond lengths $(\AA)$ and angles $\left(^{\circ}\right)$ determined for 2.

\begin{tabular}{|lc|}
\hline \hline & 2 \\
\hline \hline $\mathrm{Mo}(1)-\mathrm{N}(1)$ & $2.070(4)$ \\
$\mathrm{Mo}(1)-\mathrm{N}(2)$ & $2.072(4)$ \\
$\mathrm{Mo}(1)-\mathrm{N}(3)$ & $2.186(4)$ \\
$\mathrm{Mo}(1)-\mathrm{P}(1)$ & $2.4301(13)$ \\
$\mathrm{Mo}(1)-\mathrm{P}(2)$ & $2.4825(13)$ \\
$\mathrm{Mo}(1)-\mathrm{C}(40)$ & $1.955(5)$ \\
$\mathrm{C}(40)-\mathrm{O}(1)$ & $1.183(6)$ \\
$\mathrm{N}(1)-\mathrm{C}(2)$ & $1.362(6)$ \\
$\mathrm{N}(3)-\mathrm{C}(8)$ & $1.323(6)$ \\
$\mathrm{C}(2)-\mathrm{C}(3)$ & $1.402(7)$ \\
$\mathrm{C}(7)-\mathrm{C}(8)$ & $1.453(7)$ \\
$\mathrm{N}(2)-\mathrm{C}(3)$ & $1.390(6)$ \\
$\mathrm{N}(2)-\mathrm{C}(7)$ & $1.368(6)$ \\
& \\
$\mathrm{N}(1)-\mathrm{Mo}(1)-\mathrm{N}(3)$ & $147.91(15)$ \\
$\mathrm{N}(1)-\mathrm{Mo}(1)-\mathrm{N}(2)$ & $74.79(15)$ \\
$\mathrm{N}(1)-\mathrm{Mo}(1)-\mathrm{C}(40)$ & $97.74(18)$ \\
$\mathrm{N}(2)-\mathrm{Mo}(1)-\mathrm{C}(40)$ & $171.43(18)$ \\
$\mathrm{P}(1)-\mathrm{Mo}(1)-\mathrm{P}(2)$ & $155.46(5)$ \\
\hline
\end{tabular}


The cyclic voltammogram of $\mathbf{2}$ in THF provides further evidence for this electronic structure assignment (Figure S9 of the Supporting Information). The reversible oxidation of $\mathbf{2}$ was found to occur at $E_{1 / 2}=-1.21 \mathrm{~V} \mathrm{vs} . \mathrm{Fc} / \mathrm{Fc}^{+}$(scan rate $=25 \mathrm{mV} / \mathrm{s}$ ). This potential is consistent with the oxidation of $\operatorname{Mo}(0)$ to $\mathrm{Mo}(\mathrm{I})$ based on previously reported carbonyl stretching frequency ${ }^{38}$ and ligand parameter ${ }^{39}$ electrochemical correlation studies. It is interesting to note that the one electron reduction of $\mathbf{2}$ is also reversible $\left(E_{1 / 2}=-2.63 \mathrm{~V} \mathrm{vs} . \mathrm{Fc} / \mathrm{Fc}^{+}\right)$, suggesting that PDI noninnocence allows the formation of a formal Mo(-I) complex that possesses a PDI radical anion.

Having characterized $\mathbf{1}$ and $\mathbf{2}$, the hydrosilylation activity of both complexes was investigated. Heating an equimolar benzene- $d_{6}$ solution of benzaldehyde and phenylsilane with $1.0 \mathrm{~mol} \%$ of either $\mathbf{1}$ or $\mathbf{2}$ to $90^{\circ} \mathrm{C}$ allowed for complete substrate reduction after $4.5 \mathrm{~h}$. While comparable activity was noted for both complexes, the optimization of $\mathbf{2}$-catalyzed aldehyde hydrosilylation was pursued since 2 can be prepared directly from $\mathrm{Mo}(\mathrm{CO})_{6}$ and ${ }^{\mathrm{Ph}}{ }^{\mathrm{PPr}} \mathrm{PDI}$ in high yield. Varying the reductant was found to dramatically impact the rate of $\mathbf{2}$-catalyzed benzaldehyde hydrosilylation (Table 3). For example, heating a benzene- $d_{6}$ solution of benzaldehyde and diphenylsilane containing $1.0 \mathrm{~mol} \%$ of 2 to $90{ }^{\circ} \mathrm{C}$ gave only $32 \%$ conversion after $4.5 \mathrm{~h}$ (Entry 2), while the use of $\mathrm{Ph}_{3} \mathrm{SiH}$ completely shut down catalysis (Entry 3). While a similar effect was noted for $\mathrm{Et}_{3} \mathrm{SiH}$, quaternary silyl ethers could be prepared when using unhindered ethoxysilanes (Entries 4-6). Although conducting the hydrosilylation of benzaldehyde with phenylsilane at 120 ${ }^{\circ} \mathrm{C}$ resulted in near complete conversion after only $1 \mathrm{~h}\left(\mathrm{TOF}=90 \mathrm{~h}^{-1}\right)$, it was found that running the reaction at $0.1 \mathrm{~mol} \% 2$ in the absence of solvent at $90{ }^{\circ} \mathrm{C}$ resulted in an improved TOF of 323 $\mathrm{h}^{-1}$ (Entry 9). These conditions were determined to be ideal for exploring the synthetic utility of 2, as minimizing energy input and solvent use are critical considerations from a sustainability standpoint. 
Table 3. The hydrosilylation of benzaldehyde using $\mathbf{2}$ as a catalyst.

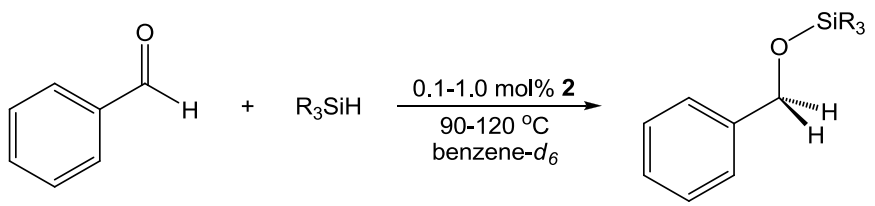

\begin{tabular}{|c|c|c|c|c|c|c|}
\hline Entry & $\begin{array}{c}\text { Temp. } \\
\left({ }^{\circ} \mathbf{C}\right)\end{array}$ & $\begin{array}{c}\text { Cat. } \\
\text { Loading } \\
(\mathrm{mol} \%)\end{array}$ & Silane & $\begin{array}{c}\text { Product } \\
\text { (Ratio) }\end{array}$ & $\begin{array}{c}\text { Time } \\
\text { (h) }\end{array}$ & $\begin{array}{c}\text { Conv. } \\
(\%)^{a}\end{array}$ \\
\hline 1 & 90 & 1.0 & $\mathrm{PhSiH}_{3}$ & $\begin{array}{c}\mathrm{PhSiH}\left(\mathrm{OCH}_{2} \mathrm{Ph}\right)_{2} \\
\mathrm{PhSiH}_{2}\left(\mathrm{OCH}_{2} \mathrm{Ph}\right) \\
(4: 1)^{\mathrm{b}}\end{array}$ & 4.5 & $>99$ \\
\hline 2 & 90 & 1.0 & $\mathrm{Ph}_{2} \mathrm{SiH}_{2}$ & $\mathrm{Ph}_{2} \mathrm{SiH}\left(\mathrm{OCH}_{2} \mathrm{Ph}\right)$ & 4.5 & 32 \\
\hline 3 & 90 & 1.0 & $\mathrm{Ph}_{3} \mathrm{SiH}$ & - & 4.5 & - \\
\hline 4 & 90 & 1.0 & $(\mathrm{EtO})_{3} \mathrm{SiH}$ & $(\mathrm{EtO})_{3} \mathrm{SiOCH}_{2} \mathrm{Ph}$ & 4.5 & 14 \\
\hline 5 & 90 & 1.0 & $(\mathrm{EtO})_{2}(\mathrm{Me}) \mathrm{SiH}$ & $(\mathrm{EtO})_{2}(\mathrm{Me}) \mathrm{SiOCH}_{2} \mathrm{Ph}$ & 4.5 & 45 \\
\hline 6 & 90 & 1.0 & $(\mathrm{EtO})(\mathrm{Me})_{2} \mathrm{SiH}$ & $(\mathrm{EtO})(\mathrm{Me})_{2} \mathrm{SiOCH}_{2} \mathrm{Ph}$ & 4.5 & 27 \\
\hline 7 & 90 & 1.0 & $\mathrm{Et}_{3} \mathrm{SiH}$ & - & 4.5 & - \\
\hline 8 & 120 & 1.0 & $\mathrm{PhSiH}_{3}$ & $\begin{array}{c}\mathrm{PhSiH}\left(\mathrm{OCH}_{2} \mathrm{Ph}\right)_{2} \\
\mathrm{PhSiH}_{2}\left(\mathrm{OCH}_{2} \mathrm{Ph}\right) \\
(2: 1)^{\mathrm{b}}\end{array}$ & 1 & 90 \\
\hline $9^{c}$ & 90 & 0.1 & $\mathrm{PhSiH}_{3}$ & $\begin{array}{c}\mathrm{PhSiH}\left(\mathrm{OCH}_{2} \mathrm{Ph}\right)_{2} \\
\mathrm{PhSi}\left(\mathrm{OCH}_{2} \mathrm{Ph}\right)_{3} \\
(2: 1)^{\mathrm{d}}\end{array}$ & 3 & 97 \\
\hline $10^{\mathrm{c}}$ & 60 & 0.1 & $\mathrm{PhSiH}_{3}$ & $\begin{array}{c}\mathrm{PhSiH}\left(\mathrm{OCH}_{2} \mathrm{Ph}\right)_{2} \\
\mathrm{PhSiH}_{2}\left(\mathrm{OCH}_{2} \mathrm{Ph}\right) \\
(2: 1)\end{array}$ & 3 & 29 \\
\hline
\end{tabular}


${ }^{\mathrm{a}}$ Percent conversion was determined by ${ }^{1} \mathrm{H}$ NMR spectroscopy. ${ }^{\mathrm{b}} \mathrm{A}$ small amount of $\mathrm{PhSi}\left(\mathrm{OCH}_{2} \mathrm{Ph}\right)_{3}$ was observed. ${ }^{\mathrm{c}}$ Trial was conducted without added benzene- $d_{6}$ (neat). ${ }^{\mathrm{d}} \mathrm{A}$ minimal amount of $\mathrm{PhSiH}_{2}\left(\mathrm{OCH}_{2} \mathrm{Ph}\right)$ was observed.

Our efforts to investigate the substrate scope of 2-catalyzed aldehyde hydrosilylation are summarized in Table 4. Since both $\mathrm{PhSiH}\left(\mathrm{OCH}_{2} \mathrm{Ph}\right)_{2}$ and $\mathrm{PhSiH}_{2}\left(\mathrm{OCH}_{2} \mathrm{Ph}\right)$ had formed following benzaldehyde hydrosilylation, the conversion of silyl ethers to their parent alcohols was conducted for several trials by treating the reaction mixture with aqueous $10 \% \mathrm{NaOH}$, in order to simplify product isolation. ${ }^{81}$ As shown in Entries 1-5, varying the electronic properties of the aldehyde had little influence on the observed TOFs. Importantly, these trials also indicate that aryl cyanide, chloride, and fluoride substituents appear to be tolerated by 2 . Although the reaction did not reach completion, the hydrosilylation of trans-cinnamaldehyde to yield cinnamyl alcohol (Entry 7) revealed that $\alpha, \beta$-unsaturation is tolerated by 2 and that the olefin is not reduced during the course of aldehyde hydrosilylation. The inability of $\mathbf{2}$ to mediate olefin hydrosilylation was further confirmed by following the hydrosilylation of 3-cyclohexene-1carboxaldehyde (Entry 9). Attempts to achieve 1-hexene or cyclohexene hydrosilylation under similar conditions were unsuccessful.

Table 4. The preparation of alcohols from aldehydes via 2-mediated hydrosilylation.

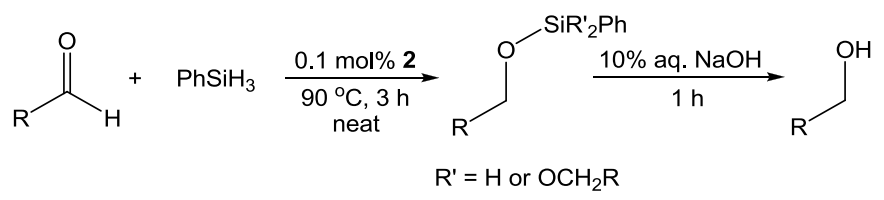

\begin{tabular}{|c|c|c|c|}
\hline Entry & Substrate & $\begin{array}{c}\text { \% Conversion } \\
{\text { (Isolated })^{\mathbf{b}}}^{\text {a }}\end{array}$ & $\begin{array}{c}\text { TOF }^{\mathrm{c}} \\
\left(\mathbf{h}^{-1}\right)\end{array}$ \\
\hline
\end{tabular}




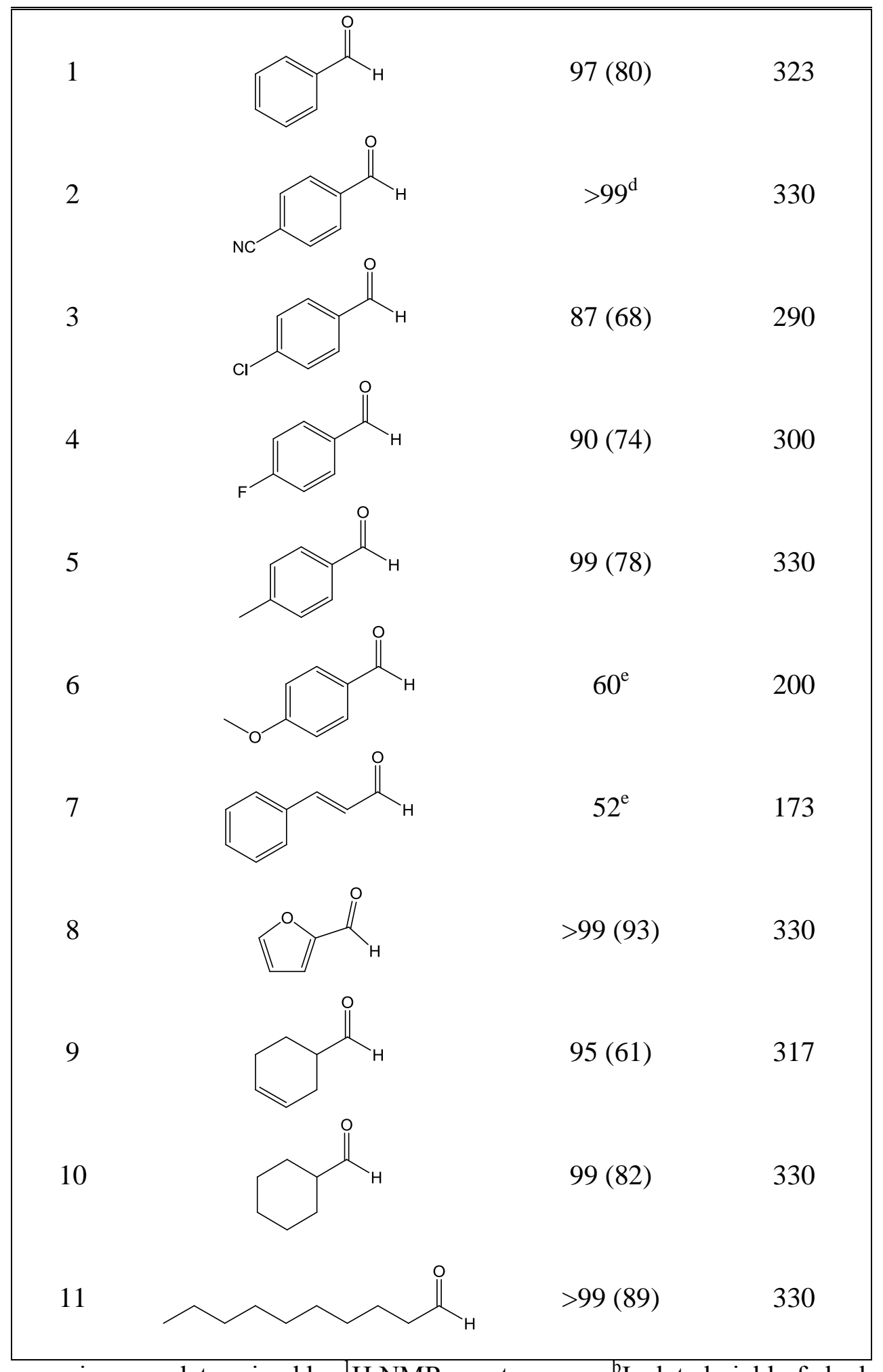

${ }^{\mathrm{a}}$ Percent conversion was determined by ${ }^{1} \mathrm{H}$ NMR spectroscopy. ${ }^{\mathrm{b}}$ Isolated yield of alcohol relative to aldehyde. ${ }^{\mathrm{c}} \mathrm{TOF}$ calculated from percent conversion. ${ }^{\mathrm{d}} \mathrm{NaOH}$ treatment resulted in conversion of the nitrile substituent to a carboxylic acid. ${ }^{e} \mathrm{NaOH}$ treatment afforded a mixture of starting aldehyde and alcohol. 
Unfortunately, attempts to catalyze the hydrosilylation of ketones (including cyclohexanone, 2hexanone, acetophenone, and diisopropyl ketone) under the conditions used to generate Table 4 were also unsuccessful. When conducting each of the ketone hydrosilylation trials, no color change was observed upon substrate addition. In contrast, preparing aldehyde or equimolar aldehyde $/ \mathrm{PhSiH}_{3}$ solutions of $\mathbf{2}$ resulted in a series of color changes whereby the starting pink solution turned bluish-purple, before reverting back to a pink-colored solution within minutes at room temperature. This observation prompted a series of experiments to further probe the interaction of the precatalyst with both $\mathrm{PhSiH}_{3}$ and aldehydes. Adding 5 eq. of $\mathrm{PhSiH}_{3}$ to 2 in benzene- $d_{6}$ solution resulted in no change after $24 \mathrm{~h}$ at either $25^{\circ} \mathrm{C}$ or $90^{\circ} \mathrm{C}$, as judged by ${ }^{1} \mathrm{H}$ and ${ }^{31} \mathrm{P}$ NMR spectroscopy. However, adding 5 eq. of benzaldehyde to 2 resulted in partial conversion to a complex with ${ }^{31} \mathrm{P}$ NMR resonances at 29.18 and $-16.51 \mathrm{ppm}$ after $1 \mathrm{~h}$ at $25^{\circ} \mathrm{C}$, suggesting that the newly formed compound possesses one coordinated and one free ${ }^{\mathrm{Ph}_{2} \mathrm{PPr}} \mathrm{PDI}$ phosphine substituent (see Figure S40 of the Supporting Information). After $48 \mathrm{~h}$ at $25^{\circ} \mathrm{C}$, a mixture of Mo-containing products with one or both ligand phosphine arms dissociated had formed (See Figures S41 and S42 of the Supporting Information). A complex mixture of Mo compounds was observed by ${ }^{31} \mathrm{P}$ spectroscopy following aldehyde hydrosilylation (See Figure S43 of the Supporting Information). Finally, conducting the hydrosilylation of benzaldehyde in the presence of $\mathrm{Hg}$ did not influence hydrosilylation TOF, indicating that heterogeneous Mo species are not responsible for the observed catalysis.

These experiments shed light on the mechanism of 2-catalyzed aldehyde hydrosilylation and offer clues as to how improved (PDI)Mo hydrosilylation catalysts might be developed. Since the facile coordination of aldehydes to $\mathbf{2}$ has been observed, it is proposed that this complex mediates hydrosilylation through the mechanism displayed in Figure 3. Starting with 2, the 
substitution of one ${ }^{\mathrm{Ph}_{2} \mathrm{PPr}} \mathrm{PDI}$ chelate arm by an aldehyde ligand is shown; however, it is possible that aldehydes displace both phosphine substituents to form $\left(\kappa^{3}-N, N, N-\right.$ $\left.{ }^{\mathrm{Ph}_{2} \mathrm{Pr}} \mathrm{PDI}\right) \mathrm{Mo}(\mathrm{CO})(\text { aldehyde })_{2}$ during the reaction. Incoming aldehydes might coordinate in either an $\eta^{1}$ - or $\eta^{2}$-fashion and are more likely to displace ${ }^{\mathrm{Ph}_{2} \mathrm{PPr}} \mathrm{PDI}$ phosphine moieties than ketones since they are less sterically demanding. ${ }^{40}$ After substrate binding, the oxidative addition of $\mathrm{PhSiH}_{3}$ would result in formation of the 7-coordinate $\mathrm{Mo}(\mathrm{II})$ complex shown at the bottom right of Figure 3. As suggested for $\left[(\mathrm{DPEphos}) \mathrm{Mo}(\mathrm{NO})(\mathrm{NCMe})_{3}\right]\left[\mathrm{BAr}_{4}^{\mathrm{F}}\right],{ }^{24}$ silane oxidative addition is likely the rate-limiting step of this transformation, in part because $\mathrm{PhSiH}_{3}$ does not independently react with $\mathbf{2}$, even after $24 \mathrm{~h}$ at $90{ }^{\circ} \mathrm{C}$. Migratory insertion of the substrate into the Mo-H bond with concomitant phosphine coordination would lead to a monoalkoxide silyl complex that undergoes reductive elimination to regenerate $\mathbf{2}$ (or an aldehyde-coordinated analogue). While the oxidative addition and insertion steps may proceed in a concerted fashion (a non-hydride pathway has been established for tetravalent Mo hydrosilylation catalysts), ${ }^{22 \mathrm{~d}}$ our proposed mechanism differs from the carbonyl hydrosilylation mechanism proposed by Ojima ${ }^{41}$ and Berke ${ }^{24}$ in that it does not rely on the formation of a high-energy tertiary alkyl complex. It is also unlikely that $\mathbf{2}$ operates by way of a silylene mechanism, ${ }^{42}$ since tertiary silanes were proven capable of mediating benzaldehyde hydrosilylation (Table 3, Entries 4-6). 

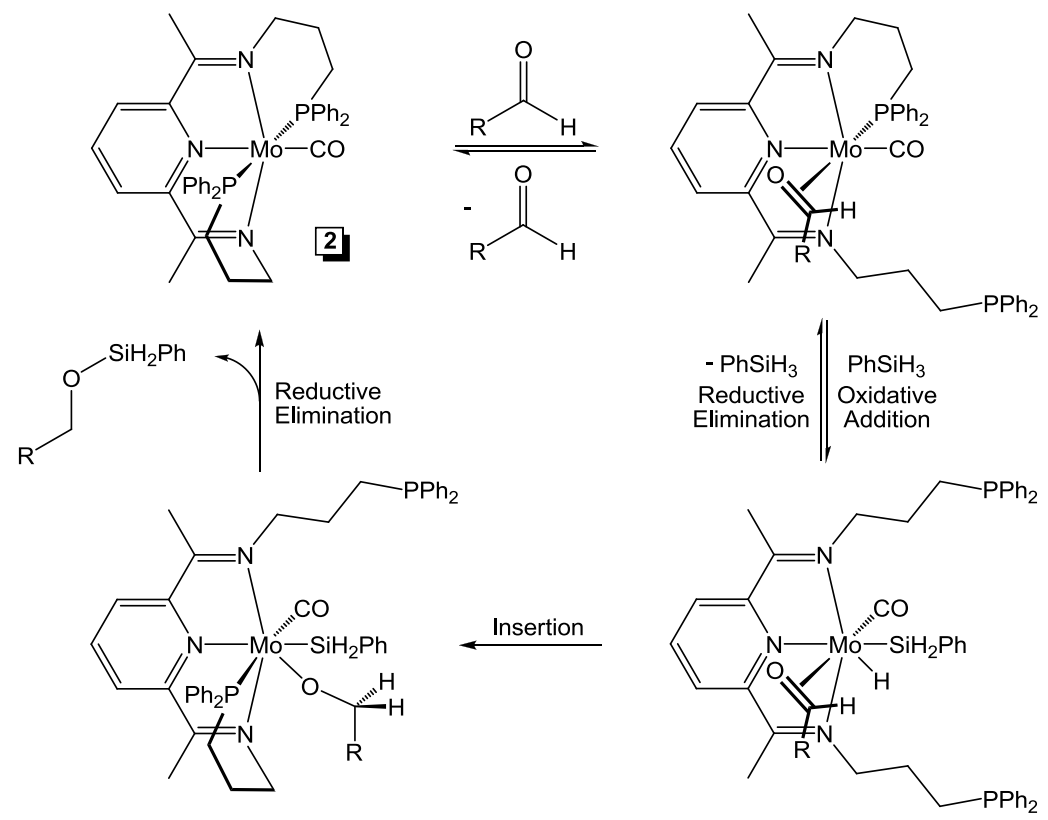

Figure 3. Proposed mechanism for 2-catalyzed aldehyde hydrosilylation.

Ultimately, it must be stated that $\mathbf{1}$ and $\mathbf{2}$ have been shown to exhibit somewhat disappointing carbonyl hydrosilylation activity when compared to [(DPEphos)Mo(NO)(NCMe) $\left.)_{3}\right]\left[\mathrm{BAr}_{4}^{\mathrm{F}}\right.$ ]. Although the $\left[(\mathrm{DPEphos}) \mathrm{Mo}(\mathrm{NO})(\mathrm{NCMe})_{3}\right]\left[\mathrm{BAr}^{\mathrm{F}}{ }_{4}\right]-$ mediated aldehyde hydrosilylation reactions reported by Berke and co-workers were conducted at $120^{\circ} \mathrm{C}$, initial TOFs of up to $4864 \mathrm{~h}^{-1}$ were observed. ${ }^{24}$ At $120^{\circ} \mathrm{C}$, 2-catalyzed benzaldehyde reduction proceeded with a TOF of only $90 \mathrm{~h}^{-1}$. One reason for this difference in activity may be that [(DPEphos)Mo(NO)(NCMe) $\left.)_{3}\right]\left[\mathrm{BAr}^{\mathrm{F}}{ }_{4}\right]$ possesses three acetonitrile ligands which are more easily displaced than the CO ligand or the phosphine arms of $\mathbf{2}$. To render the metal center more accessible, we are currently working to prepare $\left(\kappa^{5}-\mathrm{PDI}\right)$ Mo catalysts that have a weak field ligand occupying their sixth coordination site. Additionally, it can be predicted that complexes of the general formula $\left(\kappa^{3}-N, N, N-\right.$ $\mathrm{PDI}) \mathrm{Mo}(\mathrm{L})_{3}$ (where $\mathrm{L}$ is a monodentate, weak-field $\sigma$-donor) might exhibit improved hydrosilylation activity when compared to $\mathbf{1}$ or $\mathbf{2}$. 
CONCLUSION. While attempts to prepare a formal Mo(0) complex featuring $\kappa^{5}-{ }^{\mathrm{PyEt}} \mathrm{PDI}$ coordination resulted in the formation of $\left(\kappa^{3}-{ }^{\mathrm{PEEt}} \mathrm{PDI}\right)_{2} \mathrm{Mo}(\mathbf{1})$, refluxing a toluene solution of ${ }_{\mathrm{Ph}}{ }_{2} \mathrm{Pr} P D I$ and $\mathrm{Mo}(\mathrm{CO})_{6}$ afforded $\left(\kappa^{5}{ }_{-}{ }_{2}{ }_{2} \mathrm{PPr} P D I\right) \mathrm{Mo}(\mathrm{CO})(2)$. The X-ray crystallographic investigation of both products revealed that electron density is being transferred from the metal to the chelate via $\pi$-backbonding in each complex; however, actual PDI ligand reduction does not appear to occur. Upon determining that $\mathbf{1}$ and $\mathbf{2}$ act as precatalysts for the hydrosilylation of benzaldehyde at $90{ }^{\circ} \mathrm{C}$, the reaction conditions were optimized using $\mathbf{2}$ and applied to the reduction of 11 different aldehydes $\left(\mathrm{TOFs}=173-330 \mathrm{~h}^{-1}\right.$ at $0.1 \mathrm{~mol} \%$ catalyst loading). Furthermore, investigating the reactivity of $\mathbf{2}$ towards phenylsilane and benzaldehyde revealed that the dissociation of ligand phosphine substituents likely accompanies catalytic turnover. In addition to demonstrating the importance of co-donor field strength in catalyst design, it is believed that the efforts described herein may guide the preparation of improved low-valent Mo hydrosilylation catalysts.

\section{EXPERIMENTAL SECTION}

General Considerations: Unless otherwise stated, all chemicals and synthetic reactions were handled under an atmosphere of purified nitrogen, either in an MBraun glove box or using standard Schlenk line techniques. Pentane, toluene, diethyl ether, and tetrahydrofuran were purchased from Sigma-Aldrich, dried using a Pure Process Technology solvent system, and stored in a glove box over activated $4 \AA$ molecular sieves and metallic sodium (from Alfa Aesar) before use. Benzene- $d_{6}$ was obtained from Cambridge Isotope Laboratories and dried over $4 \AA$ molecular sieves and metallic sodium prior to use. 2,6-Diacetylpyridine, 2-(2aminoethyl)pyridine, triethoxysilane, decanal, 4-chlorobenzaldehyde, 3-cyclohexene-1- 
carboxaldehyde, and trans-cinnamaldehyde were purchased from TCI America. 4Cyanobenzaldehyde, phenylsilane, diphenylsilane, and triphenylsilane were purchased from Oakwood Products. Cyclohexanecarboxaldehyde, $p$-tolualdehyde, furfural, pyridine, triethylsilane, diethoxymethylsilane, dimethoxyethylsilane, benzaldehyde, and $p$-anisaldehyde were purchased from Sigma-Aldrich. Celite, anhydrous sodium sulfate, sodium hydroxide, $m$ xylene, and $p$-fluorobenzaldehyde were purchased from Acros and used as received. $\mathrm{Mo}(\mathrm{CO})_{6}$ and 3-(diphenylphosphino)propylamine were purchased from Strem Chemicals and used as

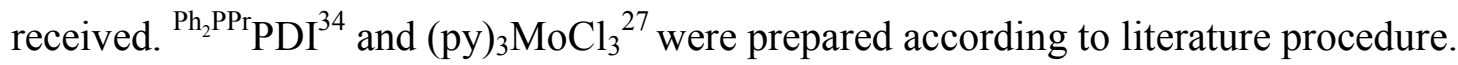

Solution phase ${ }^{1} \mathrm{H},{ }^{13} \mathrm{C}$, and ${ }^{31} \mathrm{P}$ nuclear magnetic resonance (NMR) spectra were recorded at room temperature on either a $400 \mathrm{MHz}$ or $500 \mathrm{MHz}$ Varian NMR Spectrometer. All ${ }^{1} \mathrm{H}$ and ${ }^{13} \mathrm{C}$ NMR chemical shifts are reported relative to $\mathrm{Si}\left(\mathrm{CH}_{3}\right)_{4}$ using ${ }^{1} \mathrm{H}$ (residual) and ${ }^{13} \mathrm{C}$ chemical shifts of the solvent as secondary standards. ${ }^{31} \mathrm{P}$ NMR data is reported relative to $\mathrm{H}_{3} \mathrm{PO}_{4}$. Solidstate IR spectroscopy was conducted on a Bruker Vertex 70 spectrometer. Elemental analyses were performed at Robertson Microlit Laboratories Inc. (Ledgewood, NJ) and Arizona State University CLAS Goldwater Environmental Laboratory (Tempe, AZ).

X-ray crystallography: Single crystals suitable for X-ray diffraction were coated with polyisobutylene oil in the glovebox and transferred to glass fiber with Apiezon $\mathrm{N}$ grease, which was then mounted on the goniometer head of a Bruker APEX Diffractometer (Arizona State Unversity) equipped with Mo Ka radiation. A hemisphere routine was used for data collection and determination of the lattice constants. The space group was identified and the data was processed using the Bruker SAINT+ program and corrected for absorption using SADABS. The structures were solved using direct methods (SHELXS) completed by subsequent Fourier 
synthesis and refined by full-matrix, least-squares procedures on $\left[\mathrm{F}^{2}\right]$ (SHELXS). The solid-state structure of $\mathbf{2}$ was found to possess a disordered diethyl ether molecule.

Calculations. All DFT calculations were carried out using the ORCA program, ${ }^{43}$ and all compounds were optimized with the B3LYP functional. ${ }^{44}$ The Conductor-like Screening Model (COSMO) was used where indicated, with THF as the solvent. ${ }^{45}$ Empirical Van der Waals corrections were included in the geometry optimizations of all molecules. ${ }^{46}$ The self-consistent field (SCF) calculations were tightly converged $\left(1 \times 10^{-8} E_{\mathrm{h}}\right.$ in energy, $1 \times 10^{-7} E_{\mathrm{h}}$ in the density charge). Ahlrichs triple- $\xi$ valence basis sets (relativistically recontracted) with one set of first polarization functions (def2-TZVP-ZORA) were used for the molybdenum and nitrogen atoms. ${ }^{47}$ Ahlrichs split valence basis sets (relativistically recontracted) with one set of first polarization functions (def2-SVP-ZORA) were used for the carbon and hydrogen atoms. ${ }^{47}$ Auxiliary basis sets were chosen to match the orbital basis sets used. Molecular orbitals were visualized using the Molekel program. ${ }^{48}$

Electrochemistry. Electrochemical experiments were conducted using a 1210B handheld potentiostat purchased from $\mathrm{CH}$ Instruments. All experiments were performed under a nitrogen atmosphere using a glassy carbon working electrode (3 $\mathrm{mm}$ diameter), a silver/silver ion reference electrode, and a platinum counter electrode that were purchased from BASi. Approximately $2 \mathrm{mg}$ of ferrocene (internal reference, Sigma-Aldrich) and 2 were added to $5 \mathrm{~mL}$ of a $0.1 \mathrm{M}$ tetrahydrofuran solution of tetrabutylammonium hexafluorophosphate (Fluka) directly before data collection. The cyclic voltammagram of $\mathbf{2}$ is reported relative to $\mathrm{Fc}^{+} / \mathrm{Fc}$. The $E_{1 / 2}$ values provided were determined by averaging the potentials of maximum anodic and cathodic current. 
Improved Preparation of 2,6-((2-NC $\left.\left.\mathrm{N}_{5} \mathrm{H}_{4}\right) \mathrm{CH}_{2} \mathrm{CH}_{2} \mathrm{~N}=\mathrm{C}\left(\mathrm{CH}_{3}\right)\right)_{2} \mathrm{C}_{5} \mathrm{H}_{3} \mathrm{~N}\left({ }^{\mathrm{PyEt}} \mathrm{PDI}\right)$ : Although

previously reported, ${ }^{26}$ an improved synthesis of this ligand is provided. A $100 \mathrm{~mL}$ thick-walled reaction bomb containing $0.20 \mathrm{~g}$ of $4 \AA$ molecular sieves was charged with $10 \mathrm{~mL}$ of toluene, $1.00 \mathrm{~g}(6.13 \mathrm{mmol})$ of 2,6-diacetylpyridine, and $0.019 \mathrm{~g}(0.11 \mathrm{mmol})$ of $p$-toluenesulfonic acid

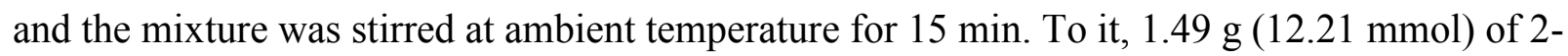
(2-aminoethyl)pyridine was added dropwise. The bomb was then sealed and heated to $80{ }^{\circ} \mathrm{C}$ for two days. The resulting orange solution was cooled to ambient temperature and filtered through Celite to remove the sieves and precipitated $p$-toluenesulfonic acid. The solvent was then evacuated to obtain $2.20 \mathrm{~g}(96 \%)$ of a deep orange oil identified as ${ }^{\text {PyEt }}$ PDI. Elemental analysis for $\mathrm{C}_{23} \mathrm{H}_{25} \mathrm{~N}_{5}$ : Calcd. C, 74.36; H, 6.78; N, 18.85. Found C, 74.21; H, 6.92; N, 18.31. ${ }^{1} \mathrm{H}$ NMR (benzene- $\left.d_{6}\right): \delta 8.58\left(\mathrm{~d}, 4.3 \mathrm{~Hz}, 2 \mathrm{H},{ }^{a} \mathrm{Py}\right), 8.30\left(\mathrm{~d}, 7.7 \mathrm{~Hz}, 2 \mathrm{H}, m^{-}{ }^{c} \mathrm{Py}\right), 7.23(\mathrm{t}, 7.7 \mathrm{~Hz}, 1 \mathrm{H}, p-$ $\left.{ }^{c} \mathrm{Py}\right), 7.05$ (t, $\left.6.9 \mathrm{~Hz}, 2 \mathrm{H},{ }^{a} \mathrm{Py}\right), 6.94\left(\mathrm{~d}, 7.8 \mathrm{~Hz}, 2 \mathrm{H},{ }^{a} \mathrm{Py}\right), 6.62\left(\mathrm{~m}, 2 \mathrm{H},{ }^{a} \mathrm{Py}\right), 3.94$ (t, $7.2 \mathrm{~Hz}, 4 \mathrm{H}$, $\left.\mathrm{CH}_{2} \mathrm{CH}_{2} \mathrm{~N}\right), 3.35\left(\mathrm{t}, 7.2 \mathrm{~Hz}, 4 \mathrm{H}, \mathrm{CH}_{2} \mathrm{CH}_{2} \mathrm{~N}\right), 2.18\left(s, 6 \mathrm{H}, \mathrm{CH}_{3}\right) .{ }^{13} \mathrm{C}$ NMR (benzene- $\left.d_{6}\right): \delta 166.77$ $(C=\mathrm{N}), 161.63\left({ }^{a} \mathrm{Py}\right), 156.73\left({ }^{c} \mathrm{Py}\right), 150.11\left({ }^{a} \mathrm{Py}\right), 136.51\left({ }^{c} \mathrm{Py}\right), 135.96\left({ }^{a} \mathrm{Py}\right), 123.87\left({ }^{a} \mathrm{Py}\right)$, $121.65\left({ }^{a} \mathrm{Py}\right), 121.41\left({ }^{c} \mathrm{Py}\right), 52.95\left(\mathrm{CH}_{2} \mathrm{CH}_{2} \mathrm{~N}\right), 40.58\left(\mathrm{CH}_{2} \mathrm{CH}_{2} \mathrm{~N}\right), 13.71\left(\mathrm{CH}_{3}\right)$.

Preparation of $\left({ }^{\mathrm{PyEt}} \mathbf{P D I}\right)_{2}$ Mo (1): Method A. In a nitrogen filled glove box, a $20 \mathrm{~mL}$ reaction vial was charged with $4.6 \mathrm{~g}$ of metallic mercury and $3 \mathrm{~mL}$ of THF. To the vial, $0.023 \mathrm{~g}$ of freshly cut sodium was added and stirred for $30 \mathrm{~min}$ to form clear sodium amalgam solution. To the stirring solution, $0.147 \mathrm{~g}(0.394 \mathrm{mmol})$ of ${ }^{\text {PyEt}} \mathrm{PDI}$ in $5 \mathrm{~mL}$ of THF and $0.087 \mathrm{~g}$ of (py) ${ }_{3} \mathrm{MoCl}_{3}$ $(0.198 \mathrm{mmol})$ in $5 \mathrm{~mL}$ of THF were added and the mixture was allowed to stir at ambient temperature for $18 \mathrm{~h}$. The brown solution was then filtered through Celite and the solvent was removed in vacuo to yield a brown solid. After washing with pentane and drying, $0.098 \mathrm{~g}(59 \%)$ of 1 was isolated. Suitable crystals for X-ray diffraction were grown from pentane. Method B. In 
a nitrogen filled glove box, a $100 \mathrm{~mL}$ thick-walled reaction bomb was charged with $0.016 \mathrm{~g}$ $(0.06 \mathrm{mmol})$ of $\mathrm{Mo}(\mathrm{CO})_{6}$ dissolved in $10 \mathrm{~mL}$ of $m$-xylene, $0.045 \mathrm{~g}(0.121 \mathrm{mmol})$ of ${ }^{\text {PyEt}} \mathrm{PDI}$ dissolved in $10 \mathrm{~mL}$ of $m$-xylene, and a magnetic stir bar. The bomb was sealed, the solution was frozen with liquid nitrogen, and the reaction was degassed on a Schlenk line. Upon warming to room temperature, the reaction was set to reflux in an oil bath that was preheated to $130{ }^{\circ} \mathrm{C}$. A color change from light yellow to brown was observed within $4 \mathrm{~h}$ of stirring. After $24 \mathrm{~h}$, the solution was cooled to room temperature, frozen with liquid nitrogen, and degassed. Once the liberated $\mathrm{CO}$ was removed, the reaction bomb was allowed to reflux for another $24 \mathrm{~h}$ at $130{ }^{\circ} \mathrm{C}$ to ensure reaction completion. After once again removing $\mathrm{CO}$, the bomb was brought inside the glove box and the resulting brown solution was filtered through Celite. After removing the $m$ xylene under vacuum, washing with $2 \mathrm{~mL}$ of pentane, and drying, recrystallization from an ether/pentane solution yielded $0.027 \mathrm{~g}(0.032 \mathrm{mmol}, 53 \%)$ of a dark brown crystalline solid identified as $\left({ }^{\mathrm{PyEt}} \mathrm{PDI}\right)_{2} \mathrm{Mo}$. Elemental analysis for $\mathrm{C}_{46} \mathrm{H}_{50} \mathrm{~N}_{10} \mathrm{Mo}$ : Calcd. C, 65.85\%, H, 6.00\%, $\mathrm{N}, 16.69 \%$. Found, $\mathrm{C}, 65.76 \%, \mathrm{H}, 5.95 \%$, N, 15.72\%. Elemental analysis on $\mathrm{C}_{46} \mathrm{H}_{50} \mathrm{~N}_{10} \mathrm{Mo}$ consistently produced low N\% values and the ${ }^{1} \mathrm{H}$ and ${ }^{13} \mathrm{C}$ NMR spectra of this complex are provided as Figures S3 and S4 of the Supporting Information as a measure of purity. ${ }^{1} \mathrm{H}$ NMR (benzene- $\left.d_{6}\right): \delta 8.27\left(\mathrm{~d}, J=3.6 \mathrm{~Hz}, 2 \mathrm{H},{ }^{\mathrm{a}} \mathrm{Py}\right), 7.85\left(\mathrm{~d}, J=7.6 \mathrm{~Hz}, 2 \mathrm{H}, m^{-}{ }^{\mathrm{c}} \mathrm{Py}\right), 7.36(\mathrm{t}, J=7.6 \mathrm{~Hz}$, $1 \mathrm{H}, p$ - $\left.{ }^{\mathrm{P}} \mathrm{Py}\right), 6.97$ (m, 2H, $\left.{ }^{\mathrm{a}} \mathrm{Py}\right), 6.46\left(\mathrm{~d}, J=4.8 \mathrm{~Hz}, 2 \mathrm{H},{ }^{\mathrm{a}} \mathrm{Py}\right), 5.98\left(\mathrm{~m}, 2 \mathrm{H},{ }^{\mathrm{a}} \mathrm{Py}\right), 2.98(\mathrm{t}, J=8.4$ $\left.\mathrm{Hz}, 4 \mathrm{H}, \mathrm{CH}_{2} \mathrm{CH}_{2} \mathrm{~N}\right), 2.77\left(\mathrm{~s}, 6 \mathrm{H}, \mathrm{CH}_{3}\right), 1.72\left(\mathrm{t}, \mathrm{J}=8.4 \mathrm{~Hz}, 4 \mathrm{H}, \mathrm{CH}_{2} \mathrm{CH}_{2} \mathrm{~N}\right) .{ }^{13} \mathrm{C}$ NMR (benzene$\left.d_{6}\right): \delta 160.06(C=\mathrm{N}), 149.31(\mathrm{py}), 147.54(\mathrm{py}), 139.58(\mathrm{py}), 135.74(\mathrm{py}), 122.89$ (py), 120.88 (py), 112.98 (py), 112.71 (py), $55.05\left(\mathrm{NCH}_{2} \mathrm{CH}_{2}\right), 38.89\left(\mathrm{NCH}_{2} \mathrm{CH}_{2}\right), 13.67\left(\mathrm{CH}_{3}\right)$.

Preparation of $\left({ }^{\mathbf{P h}_{2} \mathbf{P P r}} \mathbf{P D I}\right) \mathbf{M o}(\mathbf{C O})$ (2): In a nitrogen filled glove box, a $100 \mathrm{~mL}$ thick-walled reaction bomb was charged with $0.025 \mathrm{~g}(0.095 \mathrm{mmol})$ of $\mathrm{Mo}(\mathrm{CO})_{6}$ dissolved in $10 \mathrm{~mL}$ of 
toluene, $0.058 \mathrm{~g}(0.095 \mathrm{mmol})$ of ${ }^{\mathrm{Ph}}$ PPr $P D I$ dissolved in $10 \mathrm{~mL}$ of toluene and a magnetic stir bar. The sealed bomb was attached to a Schlenk line, submerged under liquid nitrogen, and degassed. After warming to ambient temperature, the reaction was refluxed to $120{ }^{\circ} \mathrm{C}$ in a preheated oil bath. A color change from light yellow to deep pink was observed within 30 min of stirring. After $24 \mathrm{~h}$, the solution was allowed to cool to room temperature and then frozen in liquid nitrogen before the vessel was degassed on the Schlenk line. Once the liberated CO gas was removed, the solution was allowed to reflux for another $24 \mathrm{~h}$ at $120^{\circ} \mathrm{C}$ to ensure completion of the reaction. After removal of $\mathrm{CO}$, the bomb was brought inside the glove box and the resulting pink solution was filtered through Celite. The solvent was removed in vacuo, the resulting solid was washed with $2 \mathrm{~mL}$ of pentane, and then dried to yield $0.06 \mathrm{~g}(0.081 \mathrm{mmol}, 86 \%)$ of a deep pink microcrystalline solid identified as $\mathbf{2}$. Single crystals suitable for X-ray diffraction were grown from concentrated solution of ether layered with pentane at $-35^{\circ} \mathrm{C}$. Elemental analysis for $\mathrm{C}_{40} \mathrm{H}_{41} \mathrm{~N}_{3} \mathrm{MoP}_{2} \mathrm{O}$ : Calcd. C, 65.13; H, 5.60; N, 5.70; Found: C, 65.25; H, 5.63; N, 5.45. ${ }^{1} \mathrm{H}$ NMR (benzene- $\left.d_{6}\right): \delta 7.74(\mathrm{~d}, 7.2 \mathrm{~Hz}, 4 \mathrm{H}, \mathrm{Ph}), 7.11(\mathrm{t}, 7.6 \mathrm{~Hz}, 4 \mathrm{H}, \mathrm{Ph}), 6.98(\mathrm{t}, 7.2 \mathrm{~Hz}, 2 \mathrm{H}, \mathrm{Ph}), 6.85$ (m, 4H, Ph), 6.80 (m, 2H, Ph), 6.65 (m, 4H, Ph), 6.59 (t, 8.0 Hz, 1H, p-Py), 6.22 (d, 8.0 Hz, 2H, $m$-Py), $4.67\left(\mathrm{~m}, 2 \mathrm{H}, \mathrm{CH}_{2}\right), 4.63\left(\mathrm{~m}, 2 \mathrm{H}, \mathrm{CH}_{2}\right), 2.70\left(\mathrm{~m}, 2 \mathrm{H}, \mathrm{CH}_{2}\right), 2.35\left(\mathrm{~m}, 2 \mathrm{H}, \mathrm{CH}_{2}\right), 1.92(\mathrm{~m}$, $\left.2 \mathrm{H}, \mathrm{CH}_{2}\right), 1.73\left(\mathrm{~m}, 2 \mathrm{H}, \mathrm{CH}_{2}\right)$ overlaps with a peak at $1.70\left(\mathrm{~s}, 6 \mathrm{H}, \mathrm{CH}_{3}\right) .{ }^{13} \mathrm{C}$ NMR (benzene- $\left.d_{6}\right)$ : $\delta 272.19$ (t, $20.5 \mathrm{~Hz}, C \mathrm{O}), 157.19$ (C=N), 145.86 (o-py), 139.54 (t, $17.5 \mathrm{~Hz}, \mathrm{Ph}), 134.92$ (t, 7.6 Hz, Ph), 132.80 (t, 5.5 Hz, Ph), 132.47 (t, 5.5 Hz, Ph), 124.86 (p-py), 105.34 (m-py), 60.41 $\left(\mathrm{NCH}_{2} \mathrm{CH}_{2}\right), 28.86\left(\mathrm{PCH}_{2} \mathrm{CH}_{2}\right), 27.60$ (t, $\left.13.4 \mathrm{~Hz}, \mathrm{PCH}_{2} \mathrm{CH}_{2}\right), 12.65\left(\mathrm{CH}_{3}\right) .{ }^{31} \mathrm{P}$ NMR (benzene$\left.d_{6}\right): \delta 34.88$ (s). IR (KBr): $v_{\mathrm{CO}}=1740 \mathrm{~cm}^{-1}$.

General procedure for silane screening: In the glovebox, a solution of silane $(0.017 \mathrm{~mL}, 0.14$ $\mathrm{mmol}$ ) and benzaldehyde $(0.014 \mathrm{~mL}, 0.14 \mathrm{mmol})$ in benzene- $d_{6}$ (approximately $0.7 \mathrm{~mL}$ ) was 
added to a $20 \mathrm{~mL}$ scintillation vial containing $0.001 \mathrm{~g}(0.0014 \mathrm{mmol})$ of complex 2 . A transient color change from pink to bluish-purple to purple was observed. The resulting solution was transferred into a $\mathrm{J}$. Young tube and the sealed tube was allowed to heat at $90^{\circ} \mathrm{C}$ for $4.5 \mathrm{~h}$ in an oil bath. The progress of the reaction was determined following analysis by ${ }^{1} \mathrm{H}$ NMR spectroscopy.

General procedure for aldehyde hydrosilylation: In the glovebox, a $20 \mathrm{~mL}$ scintillation vial containing $0.0014 \mathrm{mmol}$ of 2 was charged with $\mathrm{PhSiH}_{3}(0.14 \mathrm{mmol})$ and aldehyde $(0.14 \mathrm{mmol})$. A momentary color change from pink to bluish-purple to pink was observed. The vial was sealed under nitrogen and the reaction was heated to $90{ }^{\circ} \mathrm{C}$ for $3 \mathrm{~h}$ before being opened to air to deactivate the catalyst. The resulting colorless solution was filtered into an NMR tube using 0.7 $\mathrm{mL}$ of benzene- $d_{6}$ solvent and hydrosilylation conversion was assayed by ${ }^{1} \mathrm{H}$ NMR spectroscopy. After evaporating the NMR solvent, the silylated products were hydrolyzed with $10 \% \mathrm{NaOH}(2$ $\mathrm{mL}$ ) while stirring at ambient temperature for $1 \mathrm{~h}$. Upon extracting the organic layer with diethyl ether $(3 \times 2 \mathrm{~mL})$ and drying over anhydrous $\mathrm{Na}_{2} \mathrm{SO}_{4}$, the product was isolated under reduced pressure. A control experiment was performed in a similar fashion by adding $0.14 \mathrm{mmol}$ of $\mathrm{PhSiH}_{3}$ and $0.14 \mathrm{mmol}$ of benzaldehyde to $0.7 \mathrm{~mL}$ of benzene- $d_{6}$ in the absence of complex 2 . The solution was monitored by ${ }^{1} \mathrm{H}$ NMR spectroscopy over time and no reaction was observed after $3 \mathrm{~h}$ at $90^{\circ} \mathrm{C}$.

\section{ASSOCIATED CONTENT}

Supporting Information. Crystallographic information obtained for 1 (CCDC-999338) and 2 (CCDC-999339), DFT calculation results, and multinuclear NMR spectroscopic data. This material is available free of charge via the Internet at http://pubs.acs.org. 


\section{AUTHOR INFORMATION}

\section{Corresponding Author}

Email: ryan.trovitch@asu.edu

Phone: (480) 727-8930

\section{Present Address}

${ }^{\S}$ Department of Chemistry \& Biochemistry, Colorado College, Colorado Springs, Colorado 80903

\section{Notes}

The authors declare no competing financial interest.

\section{ACKNOWLEDGMENT}

We would like to thank the Research Corporation for Science Advancement for supporting the synthetic aspects of this work as part of a Scialog Collaborative Innovation Award.

\section{REFERENCES}

${ }^{1}$ Collman, J. P.; Hegedus, L. S.; Norton, J. R.; Finke, R. G. Principles and Applications of Organotransition Metal Chemistry; University Science Books: Sausalito, CA, 1987; pp 523-575.

2 (a) Noyori, R. Angew. Chem. Int. Ed. 2002, 41, 2008-2022. (b) Carey, J. S.; Laffan, D.; Thomson, C.; Williams, M. T. Org. Biomol. Chem. 2006, 4, 2337-2347.

${ }^{3}$ Parshall, G. W.; Ittel, S. D. in Homogeneous Catalysis: The Applications and Chemistry of Catalysis by Soluble Transition Metal Complexes, 2nd Edition, John Wiley \& Sons, Inc., New York, 1992, pp. 39-41. 
${ }^{4}$ For examples of commonly used hydrosilylation catalysts see: (a) Speier, J. L.; Webster, J. A.; Barnes, G. H. J. Am. Chem. Soc. 1957, 79, 974-979. (b) Hitchcock, P. B.; Lappert, M. F.; Warhurst, N. J. W. Angew. Chem. Int. Ed. 1991, 30, 438-440.

5 (a) Enthaler, S.; Junge, K.; Beller, M. Angew. Chem. Int. Ed. 2008, 47, 3317-3321. (b) Czaplik, W. M.; Mayer, M.; Cvengroš, J.; van Wangelin, A. J. Chem. Sus. Chem. 2009, 2, 396417.

${ }^{6}$ (a) Gaillard, S.; Renaud, J.-L. Chem. Sus. Chem. 2008, 1, 505-509. (b) Troegel, D.; Stohrer, J. Coord. Chem. Rev. 2011, 255, 1440-1459.

${ }^{7}$ (a) Pratt, S. L.; Faltynek, R. A. J. Organomet. Chem. 1983, 258, C5-C8. (b) Hilal, H. S.; AbuEid, M.; Al-Subu, M.; Khalaf, S. J. Mol. Catal. 1987, 39, 1-11. (c) Mao, Z.; Gregg, B. T.; Cutler, A. R. J. Am. Chem. Soc. 1995, 117, 10139-10140. (d) Cavanaugh; M. D.; Gregg, B. T.; Cutler, A. R. Organometallics 1996, 15, 2764-2769. (e) Son, S. U.; Paik, S.-J.; Lee, I. S.; Lee, Y.-A.; Chung, Y. K.; Seok, W. K.; Lee, H. N. Organometallics 1999, 18, 4114-4118. (f) Son, S. U.; Paik, S.-J.; Chung, Y. K. J. Mol. Catal. A: Chem. 2000, 151, 87-90. (g) Chidara, V. K.; Du, G. Organometallics 2013, 32, 5034-5037. (h) Zheng, J.; Chevance, S.; Darcel, C.; Sortais, J.-B. Chem. Commun. 2013, 49, 10010-10012. (i) Mukhopadhyay, T. K.; Flores, M.; Groy, T. L.; Trovitch, R. J. J. Am. Chem. Soc. 2014, 136, 882-885.

${ }^{8}$ For representative Fe hydrosilylation catalysts see: (a) Brunner, H.; Fisch, K. Angew. Chem. Int. Ed. 1990, 29, 1131-1132. (b) Tondreau, A. M.; Lobkovsky, E.; Chirik, P. J. Org. Lett. 2008, 10, 2789-2792. (c) Langlotz, B. K.; Wadepohl, H.; Gade, L. H. Angew. Chem. Int. Ed. 2008, 47, 4670-4674. (d) Tondreau, A. M.; Darmon, J. M.; Wile, B. M.; Floyd, S. K.; Lobkovsky, E.; Chirik, P. J. Organometallics 2009, 28, 3928-3940. (e) Inagaki, T.; Ito, A.; Ito, J.; Nishiyama, H. 
Angew. Chem. Int. Ed. 2010, 49, 9384-9387. (f) Kandepi, V. V. K. M.; Cardoso, J. M. S.; Peris, E.; Royo, B. Organometallics 2010, 29, 2777-2782. (g) Yang, J.; Tilley, T. D. Angew. Chem. Int. Ed. 2010, 49, 10186-10188. (h) Bhattacharya, P.; Krause, J. A.; Guan, H. Organometallics 2011, 30, 4720-4729. (i) Atienza, C. C. H.; Tondreau, A. M.; Weller, K. J.; Lewis, K. M.; Cruse, R. W.; Nye, S. A.; Boyer, J. L.; Delis, J. G. P.; Chirik, P. J. ACS Catal. 2012, 2, 2169-2172. (j) Tondreau, A. M.; Atienza, C. C. H.; Darmon, J. M.; Milsmann, C.; Hoyt, H. M.; Weller, K. J.; Nye, S. A.; Lewis, K. M.; Boyer, J.; Delis, J. G. P.; Lobkovsky, E.; Chirik, P. J. Organometallics 2012, 31, 4886-4893. (k) Tondreau, A. M.; Atienza, C. C. H.; Weller, K. J.; Nye, S. A.; Lewis, K. M.; Delis, J. G. P.; Chirik, P. J. Science 2012, 335, 567-570. (1) Ruddy, A. J.; Kelly, C. M.; Crawford, S. M.; Wheaton, C. A.; Sydora, O. L.; Small, B. L.; Stradiotto, M.; Turculet, L. Organometallics 2013, 32, 5581-5588. (m) Peng, D.; Zhang, Y.; Du, X.; Zhang, L.; Leng, X.; Walter, M. D.; Huang, Z. J. Am. Chem. Soc. 2013, 135, 19154-19166.

${ }^{9}$ For representative Co hydrosilylation catalysts see: (a) Brunner, H.; Amberger, K. J. Organomet. Chem. 1991, 417, C63-C65. (b) Brookhart, M.; Grant, B. E. J. Am. Chem. Soc. 1993, 115, 2151-2156. (c) Tojo, S.; Isobe, M. Tetrahedron Lett. 2005, 46, 381-384. (d) Yong, L.; Kirleis, K.; Butenschön, H. Adv. Synth. Catal. 2006, 348, 833-836. (e) Konno, T.; Taku, K.; Yamada, S.; Moriyasu, K.; Ishihara, T. Org. Biomol. Chem. 2009, 7, 1167-1170. (f) Inagaki, T.; Phong, L. T.; Furuta, A.; Ito, J.; Nishiyama, H. Chem. Eur. J. 2010, 16, 3090-3096. (g) Yu, F.; Zhang, X.-C.; Wu. F.-F.; Zhou, J.-N.; Fang, W.; Wu, J.; Chan, A. S. C. Org. Biomol. Chem. 2011, 9, 5652. (h) Sauer, D. C.; Wadepohl, H.; Gade, L. H. Inorg. Chem. 2012, 51, 1294812958. (i) Niu, Q.; Sun, H.; Li, X.; Klein, H.-F.; Flörke, U. Organometallics 2013, 32, 52355238. 
${ }^{10}$ For representative Ni hydrosilylation catalysts see: (a) Tamao, K.; Miyake, N.; Kiso, Y.; Kumada, M. J. Am. Chem. Soc. 1975, 97, 5603-5605. (b) Tamao, K.; Kobayashi, K.; Ito, Y. J. Am. Chem. Soc. 1989, 111, 6478-6480. (c) Chakraborty, S.; Krause, J. A.; Guan, H. Organometallics 2009, 28, 582-586. (d) Tran, B. L.; Pink, M.; Mindiola, D. J. Organometallics 2009, 28, 2234-2243. (e) Porter, T. M.; Hall, G. B.; Groy, T. L.; Trovitch, R. J. Dalton Trans. 2013, 42, 14689-14692. (f) Miller, Z. D.; Li, W.; Belderrain, T. R.; Montgomery, J. J. Am. Chem. Soc. 2013, 135, 15282-15285. (g) Postigo, L.; Royo, B. Adv. Synth. Catal. 2012, 354, 2613-2618. (h) Bheeter, L. P.; Henrion, M.; Brelot, L.; Darcel, C.; Chetcuti, M. J.; Sortais, J.-B.; Ritleng, V. Adv. Synth. Catal. 2012, 354, 2619-2624. (i) MacMillan, S. N.; Harman, W. H.; Peters, J. C. Chem. Sci. 2014, 5, 590-597.

${ }^{11}$ (a) Morris, R. H. Chem. Soc. Rev. 2009, 38, 2282-2291. (b) Bullock, R. M. Catalysis without Precious Metals; Wiley-VCH: Weinheim, Germany, 2010. (c) Junge, K.; Schroeder, K.; Beller, M. Chem. Commun. 2011, 47, 4849-4859.

${ }^{12}$ Molybdenum is the only second row metal that is widely utilized in biological systems. For a recent review see: Hille, R.; Hall, J.; Basu, P. Chem. Rev. 2014, 114, 3963-4038.

${ }^{13}$ Haynes, W. M. CRC Handbook of Chemistry and Physics: A Ready-reference Book of Chemical and Physical Data, 94th ed.; Taylor \& Francis, Boca Raton, FL, 2013-2014.

${ }^{14}$ Fuchikami, T.; Ubukata, Y.; Tanaka, Y. Tetrahedron Lett. 1991, 32, 1199-1202.

${ }^{15}$ Baricelli, P. J.; Melean, L. G; Ricardes, S.; Guanipa, V.; Rodriguez, M.; Romero, C.; Pardey, A. J.; Moya, S.; Rosales, M. J. Organomet. Chem. 2009, 694, 3381-3385. 
16 (a) Bullock, R. M.; Voges, M. H. J. Am. Chem. Soc. 2000, 122, 12594-12595. (b) Voges, M. H.; Bullock, R. M. J. Chem. Soc., Dalton Trans. 2002, 759-770. (c) Kimmich, B. F. M.; Fagan, P. J.; Hauptman, E.; Bullock, R. M. Chem. Commun. 2004, 1014-1015. (d) Kimmich, B. F. M.; Fagan, P. J.; Hauptman, E.; Marshall, W. J.; Bullock, R. M. Organometallics 2005, 24, 62206229.

${ }^{17}$ Namorado, S.; Antunes, M. A.; Veiros, L. F.; Ascenso, J. R.; Duarte, M. T.; Martins, A. M. Organometallics 2008, 27, 4589-4599.

${ }^{18}$ (a) Adams, K. P.; Joyce, J. A.; Nile, T. A.; Patel, A. I.; Reid, C. D.; Walters, J. M. J. Mol. Catal. 1985, 29, 201-208. (b) Keinan, E.; Perez, D. J. Org. Chem. 1987, 52, 2576-2580. (c) Abdelquader, W.; Ozkar, S.; Peynircioglu, N. B. Z. Naturforsch. B: Chem. Sci. 1993, 48, 539540. (d) Schmidt, T. Tetrahedron Lett. 1994, 35, 3513-3516. (e) Kayran, C.; Rouzi, P. Z. Naturforsch. B: Chem. Sci. 2001, 56, 1138-1142. (f) Stosur, M.; Symańska-Buzar, T. J. Mol. Catal. A: Chem. 2008, 286, 98-105.

${ }^{19}$ Dioumaev, V. K.; Bullock, R. M. Nature 2003, 424, 530-532.

${ }^{20}$ (a) Fernandes, A. C.; Fernandes, R.; Romão, C. C.; Royo, B. Chem. Commun. 2005, 213214. (b) Reis, P. M.; Romão, C. C.; Royo, B. Dalton Trans. 2006, 1842-1846. (c) Pontes da Costa, A.; Reis, P. M.; Gamelas, C.; Romão, C. C.; Royo, B. Inorg. Chim. Acta 2008, 361, 19151921.

${ }^{21}$ Ziegler, J. E.; Du, G.; Fanwick, P. E.; Abu-Omar, M. M. Inorg. Chem. 2009, 48, 1129011296. 
22 (a) Khalimon, A. Y.; Simionescu, R.; Kuzmina, L. G.; Howard, J. A. K.; Nikonov, G. I. Angew. Chem. Int. Ed. 2008, 47, 7701-7704. (b) Oeterson, E.; Khalimon, A. Y.; Simionescu, R.; Kuzmina, L. G.; Howard, J. A. K.; Nikonov, G. I. J. Am. Chem. Soc. 2009, 131, 908-909. (c) Shirobokov, O. G.; Gorelsky, S. I.; Simionescu, R.; Kuzmina, L. G.; Nikonov, G. I. Chem. Commun. 2010, 46, 7831-7833. (d) Shirobokov, O. G.; Kuzmina, L. G.; Nikonov, G. I. J. Am. Chem. Soc. 2011, 133, 6487-6489. (e) Khalimon, A. Y.; Ignatov, S. K.; Simionescu, R.; Kuzmina, L. G.; Howard, J. A. K.; Nikonov, G. I. Inorg. Chem. 2012, 51, 754-756. (f) Khalimon, A. Y.; Shirobokov, O. G.; Peterson, E.; Simionescu, R.; Kuzmina, L. G.; Howard, J. A. K.; Nikonov, G. I. Inorg. Chem. 2012, 51, 4300-4313. (g) Khalimon, A. Y.; Ignatov, S. K.; Okhapkin, A. I.; Simionescu, R.; Kuzmina, L. G.; Howard, J. A. K.; Nikonov, G. I. Chem. Eur. J. 2013, 19, 8573-8590.

${ }^{23}$ (a) Arias-Ugarte, R.; Sharma, H. K.; Morris, A. L. C.; Pannell, K. H. J. Am. Chem. Soc. 2012, 134, 848-851. (b) Sharma, H. K.; Arias-Ugarte, R.; Tomlinson, D.; Gappa, R.; MettaMagaña, A. J.; Ito, H.; Pannell, K. H. Organometallics 2013, 32, 3788-3794.

${ }^{24}$ Chakraborty, S.; Blacque, O.; Fox, T.; Berke, H. ACS Catal. 2013, 3, 2208-2217.

25 Trovitch, R. J. Synlett 2014, 25, 1638-1642.

${ }^{26}$ Chiericato Jr., G.; Arana, C. R.; Casado, C.; Cusdrado, I.; Abruña, H. D. Inorg. Chim. Acta 2000, 300-302, 32-42.

${ }^{27}$ Zeng, D.; Hampden-Smith, M. J. Polyhedron 1992, 11, 2585-2589.

28 Several complexes featuring $\kappa^{2}-N, N$-PDI coordination have been identified. For crystallographically characterized examples see: (a) Lu, S.; Selbin, J. Inorg. Chim. Acta 1987, 
134, 229-232. (b) Heard, P. J.; Tocher, D. A. J. Chem. Soc., Dalton Trans. 1998, 2169-2176. (c) Cosquer, N.; Le Gall, B.; Conan, F.; Kerbaol, J.-M.; Sala-Pala, J.; Kubicki, M. M.; Vigier, E. Inorg. Chim. Acta 2006, 359, 4311-4316.

${ }^{29}$ Hiya, K.; Nakayama, Y.; Yasuda, H. Macromolecules 2003, 36, 7916-7922.

${ }^{30}$ de Bruin, B.; Bill, E.; Bothe, E.; Weyhermüller, T.; Wieghardt, K. Inorg. Chem. 2000, 39, 2936-2947.

${ }^{31}$ Knijnenberg, Q.; Gambarotta, S.; Budzelaar, P. H. M. Dalton Trans. 2006, 5442-5448.

32 PDI redox-activity has proven to be important for enabling first-row metal catalyzed transformations. For a leading example see: Chirik, P. J.; Wieghardt, K. Science 2010, 327, 794795.

${ }^{33}$ Corn, I. R.; Astudillo-Sánchez, P. D.; Zdilla, M. J.; Fanwick, P. E.; Shaw, M. J.; Miller, J. T.; Evans, D. H.; Abu-Omar, M. M. Inorg. Chem. 2013, 52, 54657-5463.

${ }^{34}$ Ben-Daat, H.; Hall, G. B.; Groy, T. L.; Trovitch, R. J. Eur. J. Inorg. Chem. 2013, 44304442.

${ }^{35}$ Chatt, J.; Leigh, G. J.; Neukomm, H.; Pickett, C. J.; Stanley, D. R. J. Chem. Soc., Dalton Trans. 1980, 121-127.

${ }^{36}$ Luo, X.-L.; Kubas, G. J.; Burns, C. J.; Butcher, R. J.; Bryan, J. C. Inorg. Chem. 1995, 34, 6538-6545.

${ }^{37}$ Complete delocalization would be expected if the electron(s) is(are) delocalized across the LUMO of the $\kappa^{3}-N, N, N$-PDI chelate (see ref. 31). It is also possible that $\kappa^{2}-N, N$-PDI chelates can 
behave as redox non-innocent ligands. For $\alpha$-iminopyridine reduction see: Lu, C. C.; Weyhermüller, T.; Bill, E.; Wieghardt, K. Inorg. Chem. 2009, 48, 6055-6064.

${ }^{38}$ Morris, R. H.; Earl, K. A.; Luck, R. L.; Lazarowych, N. J.; Sella, A. Inorg. Chem. 1987, 26 , 2674-2683.

${ }^{39}$ Lever, A. B. P. Inorg. Chem. 1990, 29, 1271-1285.

${ }^{40}$ If $\eta^{1}$-substrate binding occurs, the steric hinderance of the carbonyl substituents would be further removed from the metal center.

${ }^{41}$ Ojima, I.; Kogure, T. Organometallics 1982, 1, 1390-1399.

${ }^{42}$ Schneider, N.; Finger, M.; Haferkemper, C.; Bellemin-Laponnaz, S.; Hofmann, P.; Gade, L. H. Chem. Eur. J. 2009, 15, 11515-11529.

${ }^{43}$ Neese, F. Orca, an Ab Initio, Density Functional and Semiempirical Electronic Structure Program Package, version 2.9.1; Max Planck Institute for Bioinorganic Chemistry: Mülheim an der Ruhr, Germany, 2012.

${ }^{44}$ (a) Becke, A. D. J. Chem. Phys. 1993, 98, 5648-5652. (b) Lee, C. T.; Yang, W. T.; Parr, R. G. Phys. Rev. B 1988, 37, 785-789.

45 (a) Klamt, A.; Schüüramann, G. J. Chem. Soc., Perkin Trans. 2 1993, 799-805. (b) Sinnecker, S.; Rajendran, A.; Klamt, A.; Diedenhofen, M.; Neese, F. J. Phys. Chem. A 2006, $110,2235-2245$.

${ }^{46}$ Grimme, S. J. Comput. Chem. 2006, 27, 1787-1799. 
${ }^{47}$ Pantazis, D. A; Chen, X. Y.; Landis, C. R.; Neese, F. J. Chem. Theory Comput. 2008, 4, 908-919.

48 Molekel, Advanced Interactive 3D-Graphics for Molecular Sciences, Swiss National Supercomputing Center. http://www.cscs.ch/molekel 
TOC Graphic:

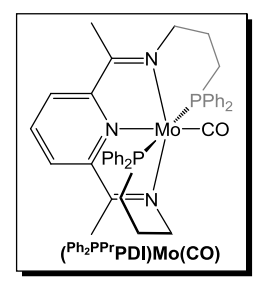

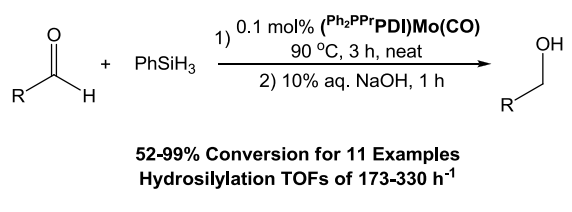

While refluxing ${ }^{\mathrm{PyEt}} \mathrm{PDI}$ and $\mathrm{Mo}(\mathrm{CO})_{6}$ resulted in the formation of $\left({ }^{\mathrm{PEE}} \mathrm{PDI}\right)_{2} \mathrm{Mo}$, conducting the same reaction with ${ }^{\mathrm{Ph}_{2} \mathrm{Pr}} \mathrm{PDI}$ afforded $\left({ }^{\mathrm{Ph}}{ }_{2} \mathrm{Pr} P D I\right) \mathrm{Mo}(\mathrm{CO})$. Both complexes were found to catalyze benzaldehyde hydrosilylation at $90{ }^{\circ} \mathrm{C}$, and the optimization of $\left({ }^{\mathrm{Ph}_{2} \mathrm{Pr}} \mathrm{PDI}\right) \mathrm{Mo}(\mathrm{CO})$ mediated aldehyde hydrosilylation resulted in turnover frequencies of up to $330 \mathrm{~h}^{-1}$. Utilizing single crystal X-ray diffraction, DFT analysis, and cyclic voltammetry, both complexes were found to possess neutral bis(imino)pyridine chelates that accept Mo-based electron density through $\pi$-backbonding. 